\title{
Emerging Infrastructure Policy Issues in Developing Countries: A Survey of the Recent Economic Literature
}

\author{
Antonio Estache \\ INFVP \\ The World Bank
}

\begin{abstract}
This paper reviews the recent economic research on emerging issues for infrastructure policies affecting poor people in developing countries. Its main purpose is to identify some of the challenges the international community, and donors in particular, are likely to have to address over the next few years. The paper addresses 6 main issues: (i) the necessity of infrastructure in achieving the Millennium Development Goals; (ii) the various dimensions of the financing challenges for infrastructure; (iii) the debate on the relative importance of urban and rural infrastructure needs; (iv) the debate on the effectiveness of infrastructure decentralization; (v) what works and what doesn't when trying to target the needs of the poor with an emphasis on the affordability and regulation challenges; (vi) the importance of governance and corruption in the sector. The paper concludes by showing how the challenges identified define a relatively well integrated agenda for both researchers and the international infrastructure community.
\end{abstract}

Background Paper for the October 2004 Berlin meeting of the POVNET Infrastructure Working Group

Please note that this paper reflects only my views. None of the ideas and interpretations here should be attributed to the World Bank or its Board of Executive Directors. I am however grateful to Ian Alexander, Judy Baker, Philippe Benoit, Jose Carbajo, Omar Chisari, Yusupha Crookes, Angel de la Fuente, Mathias Dewatripont, Severine Dinghem, Marianne Fay, Andres Gomez-Lobo, Jose-Luis Guasch, Tony Gomez-Ibanez, Jose-Luis Irigoyen, Patrick Legros, Dany Leipziger, Joseph Narkevic, Paul Noumba, Luiz Pereira, Martin RodriguezPardina, Emile Quinet, Hossein Razavi, Richard Schlirf, Tomas Serebrisky, Luis Serven, Lourdes Trujillo, Christian von Hirschausen, Jonathan Walters, Quentin Wodon and Michel Wormser for useful discussions on many of the issues addressed in the paper. They all influenced the discussion but I am the only one to blame for any misinterpretation or mistake. 


\section{Introduction}

This paper reviews the recent economic research on emerging issues for infrastructure policies affecting poor people in developing countries. Its main purpose is to identify some of the challenges the international community, and donors in particular, are likely to have to address over the next few years. Though the literature on infrastructure is relatively modest relative to the academic coverage of other public services such as education and health, its specialized and technical sectoral coverage is still too large to be given fair treatment here. Thus this is a very selective survey of the three main sources of policy-oriented research on infrastructure:

- Academic journals

- Donors and other international organizations

- $\quad$ The World Wide Web. ${ }^{1}$

Academic journals have a major advantage over the two other sources of research: they impose standard, generally demanding academic quality controls-typically involving blind peer reviews of the analytical tools and diagnostics used by researchers. In addition, these journals are ranked by the academic market (although their rankings are the subject of heated debates in the academic community). This process generates fairly high accountability for the validity of the policy messages emerging from academic research. Academic journals also have a disadvantage. For a variety of reasons, most policy issues are seldom treated as specifically as country authorities would like them to be for immediate use on the ground. Still, the top-ranked journals tend to be important opinion-makers and hence are a useful source of information on emerging issues.

There are two main types of coverage of policy issues in the academic literature. Sectoral coverage tends to address issues targeted to specific infrastructure sub-sectors (i.e. energy, telecommunications or transport) or to the whole infrastructure sector and generally has a bias toward microeconomic policy issues associated with the sector (such as regulation, technological choices, pricing, investments, and cost-benefit analysis). Generic thematic coverage of policy issues tends to be addressed in more development oriented publications and included in the discussion of a wide range of more strategic policies (e.g fiscal, trade, privatization, safety nets, environmental).

The specialized (sub-)sectoral literature on infrastructure has been impressively active since the early 1990s. And while it generally focuses on issues in industrial countries, an increasing amount covers concerns specific to developing countries. Relevant journals include Energy Economics, Energy Journal, Information Economics and Policy, Journal of Transport Economics and Policy, Journal of Housing Policy, Journal of Urban Economics, Transport Policy, Transport Reviews, Telecommunications Policy, and Water Policy. All of these journals have been major drivers of the growing knowledge and of the debates on emerging policy issues in the sectors they cover. Of equal importance at the microeconomic level are the many publications focused on thematic issues (e.g. regulation, pricing or financing) often addressed at a more general sector level including the Journal of Regulatory Economics, International Journal of Industrial Organization, Journal of Industrial Economics, and Rand Journal of Economics. In

\footnotetext{
${ }^{1}$ Because of oversight or ignorance, the survey probably excludes references, including many books, that should have been included, and for that I apologize.
} 
fact, this sector wide thematic oriented literature may have been the most dynamic over the past 10 or so years, with the birth of many new academic journals (such as the Journal of Infrastructure Systems, Journal of Network Industries, Review of Network Economics, and Utilities Policy) and a number of publications aimed at a wider audience (Infrastructure Journal, Infrastructure Finance, Project Finance, Project Finance International).

The more strategic and development policy oriented literature has focused more on emerging cross-sectoral issues, however, journals aimed at more macro-oriented policymakers seem to have a dominant role. This is because their readership includes a wider range of decisionmakers in developing countries, and any review of emerging policy issues in infrastructure must reflect their concerns. The leading journals specializing in developing countries are Development Economics, Economic Development and Cultural Change, Economics of Transition, Journal of African Economies, Journal of Development Economics, Journal of Development Studies, Journal of Economic Growth, Oxford Development Studies, Review of Development Economics, World Bank Economic Review, World Bank Research Observer, and World Development. The top economic journals accepting empirical articles on a wide range of policy issues-such as the American Economic Review, Economic Journal, Journal of Economic Perspectives, Journal of Political Economy, Journal of Productivity Analysis, Journal of Public Economics, and Quarterly Journal of Economics - also provide fair coverage of emerging issues in developing countries, including in infrastructure.

Significant economic research on infrastructure also comes from major international organizations such as the International Labour Organization (ILO), Organisation for Economic Co-operation and Development (OECD), United Nations (UN), International Energy Agency (IEA), World Health Organization (WHO), World Bank, bilateral agencies, major nongovernmental organizations (NGOs) such as Oxfam, and regional development banks such as the Asian Development Bank (ADB), European Bank for Reconstruction and Development (EBRD), Inter-American Development Bank (IDB), and African Development Bank (AfDB). Their main goals tend to be to disseminate information quickly, often with a view toward increasing accountability - at least political, if not always analytical - to facilitate research by academics, and sometimes to advocate their policy visions. In contrast to more academic research, these organizations tend to provide pragmatic views of the challenges to be addressed, particularly on country-specific issues.

Although most of these organizations have internal control systems (including both ex ante reviews and ex post audits), much of their output is not subject to the same level of technical control and rigor as academic publications. Indeed, the emphasis is often much more on pragmatism and immediate policy relevance to specific policymakers than on analytical rigor. In fact, more rigorous analysis capable of passing tougher analytical quality controls usually crosses the bridge and gets published in academic journals. One "built-in" quality control, however, is that many of the books financed by these organizations are written by or in collaboration with academic authors, who generally provide their own quality controls to avoid the reputational risks associated with contributing to bad publications.

There are an amazing number of documents on the Web from various sources, including academics and NGOs. While a fair share of this literature manages to make its way to the media and hence contributes to debates on emerging policy issues, most of it is not subject to transparent quality control. (De facto, few of these documents make it to the academic literature.) That is why these contributions are not covered in this survey. Still, such research probably deserves specific 
coverage in the future, to get a sense of the variety of visions among NGOs and the strength of their analytical support.

The above three sources of policy-oriented infrastructure research are useful complements in assessing emerging issues. Indeed, the robustness of the new visions and issues emerging from the international community's publications can be assessed by checking the consistency of the messages across "providers" of economic research-with the real test provided by the mainstreaming of the issues in the academic publications where data and ideas tend to be tortured by researchers until a truth emerges. ${ }^{2}$

The paper is organize as follows. Section 2 discusses the complementarity of infrastructure in achieving the Millennium Development Goals. Section 3 covers the financing of infrastructure. Section 4 addresses the debate on the relative importance of urban and rural infrastructure needs. Section 5 reviews the latest developments on the decentralization debate. Section 6 presents the wide literature on targeting the needs of the poor with an emphasis on a discussion of the affordability and regulation challenges. Section 7 is about governance and corruption Section 8 concludes showing how the challenges identified in each of the earlier sections define a relatively well integrated agenda for both researchers and the international infrastructure community.

\section{Infrastructure, Growth, and the Millennium Development Goals}

This section first assesses the general issue of infrastructure's macroeconomic effects, focusing on growth and productivity, an issue that continues to inspire worldwide academic and policy debates. The discussion then considers how infrastructure interacts with the Millennium Development Goals. Although few of the goals make specific reference to infrastructure, the issues and debates they raise are of enormous importance to developing countries.

\section{Infrastructure's effects on growth and productivity}

Over the past 15 or so years more than 150 published papers in English, French, or Spanish—and at least as many unpublished ones-have analyzed the macroeconomic effects of infrastructure. Accordingly, this is probably the most widely covered theme in the economic literature on infrastructure, as well as the best known outside the infrastructure community. This literature boom has mainly been the result of conceptual and technical developments associated with new growth theory and associated discussions of regional policies (see de la Fuente 2002 for a survey that includes a discussion of infrastructure).

Among the most useful outcomes of this literature has been a debate on the actual importance of infrastructure spending at different stages of development. The main message from this literature seems to be that the effective relevance of infrastructure spending is an empirical matter, and that infrastructure matters most in low-income countries or in low-income regions in richer countries.

The most common way of quantitatively assessing the effective relevance of infrastructure spending is to estimate social economic rates of return of past and new investments using a production function. Most of the academic literature estimates these returns using macroeconomic

\footnotetext{
${ }^{2}$ Numerous books should ideally be included in this survey but receive only selective coverage.
} 
growth regressions. These are usually calculated using data for a specific country or group of countries over several years. In recent years these methods have suggested economic returns on investment projects averaging 30-40 percent for telecommunications, more than 40 percent for electricity generation, and more than 200 percent for roads (although when the outliers are excluded, the average is about 80 percent for roads. Returns tend to be higher in low-income than in middle-income countries (see Canning and others 2000 and Briceño and others 2004).

New growth theory has also analyzed factors leading to convergence-and disparities_of growth rates between poor and rich regions within and across countries. This research has generated comparative rankings of sectors across regions in the same country, showing that one size does not fit all when it comes to assessing a country's public investment needs. (See de la Fuente and Vives 1995, in an analysis of Spain, for a perfect example of how creative empirics building on good theory can guide public investment decisions.)

There is also a specialized literature on urban and regional policies (new economic geography theory), which boomed following the seminal contribution by Krugman (1991). Its basic concern is how firms decide on the locations for their production. The main tradeoff is between market proximity and production concentration, and is driven by transportation costs and economies of scale in production. But many other factors are also relevant, causing this literature to develop at an amazing pace. (See Baldwin and others 2003 for a recent overview, including a chapter on the relevance of infrastructure for effective regional policies.) This progress has had important ramifications for urban economics and its effects on countries' international competitiveness (see Fujita and others 1999 for an overview), and made a major contribution to the conceptualization of regional economics offered by Fujita and Thisse (2002). Although it relies on much less empirical evidence than does new growth theory, from an infrastructure perspective the main message of this literature is its refinement of the macroeconomic literature in the context of cities and regions.

Finally, many donors systematically generate less academically publicized more microeconomic analyses of infrastructure's social impacts. Indeed, the social returns to infrastructure can be calculated from cost-benefit analysis at the project level (Briceno and others 2004). Because all multilateral and most bilateral donors use cost-benefit analysis to estimate such returns, a potentially large database is available to assess the robustness of macroeconomic information. Every donor agency should be able to provide this information. For instance, among World Bank infrastructure projects that had at least 95 percent of loan commitments disbursed between 1999 and 2003, the average economic return was 35 percent, with a spread ranging from 19 percent for water and sanitation projects to 43 percent for transport. This provides a global quantitative sense of the contribution that infrastructure investment makes to poverty reduction efforts. The Bank's average return is especially high given that it is often closer to a financial rate of return than a true economic rate of return and ignores many of the externa lities that theory recommends to include---often simply because the data are not available. The main limitation may be that there is no systematic consistency in the rigor and assumptions made on common issues across sectors.

Overall, findings from macroeconomic and microeconomic approaches are largely consistent in their assessments of high social returns to infrastructure projects as well as in their rankings of sectors, with strong evidence of the large socioeconomic benefits of transport projects. 


\section{Infrastructure's interactions with the Millennium Development Goals}

A large share of foreign aid is now oriented toward achieving the Millennium Development Goals (MDGs). ${ }^{3}$ Among other things these targets-endorsed by 189 countries at the September 2000 UN Millennium Summit-aim to, by 2015, halve the proportion of people living in extreme poverty, dramatically improve education and health systems, and protect the environment in developing countries. Although there is considerable policy debate on whether the goals are likely to be achieved (see Ravallion 2003), the academic debate has so far mostly focused on measurement issues.

Both the policy and the academic debates on MDGs have been a source of some frustration for infrastructure practitioners. Except for water and sanitation and to some extent telecommunications, there is a sense that the goals fail to recognize the relevance of transport and to a lesser extent energy (since rural energy was recently added as a priority) in the fight against poverty. ${ }^{4}$ This is partly because there is little knowledge about the basic relationship between infrastructure coverage and household income. Only two recent studies establish this relationship: Komives and others (2001) for 15 countries around the world and Estache and others (2002) for Latin American countries. ${ }^{5}$

The frustration among practitioners has not been met by academics. Indeed, while there has been a lot of talk about the MDGs in the development community and many publications on the health and education goals, there has been little academic work on the water and sanitation goals or the MDG gaps.

Leipziger and others (2003) provide the first empirical analysis of the determinants of three child health outcomes related to the MDGs: the infant mortality rate, child mortality rate, and prevalence of malnutrition. Using data from Demographic and Health Surveys (DHS), the authors go beyond the traditional cross-country regressions of new growth theory-exploiting the variability in outcomes and explanatory variables observed between asset quintiles within countries. They show that apart from traditional variables (income, assets, education, direct health interventions), better access to basic infrastructure services plays an important role in improving child health outcomes. Their analysis of interaction effects between interventions also suggests the importance of combining interventions to achieve the MDGs.

Jayasuriya and Wodon (2003) complement those findings by demonstrating the inefficiency of policies implemented by the international community and countries themselves in trying to reach the MDGs. These concerns are increasingly being voiced by key actors in international organizations: Manning (2004) for the OECD in a speech at the World Institute for Development Economics Research, Sachs and his colleagues at Colombia University for the UN in MDG papers posted on an earmarked Website, and Bourguignon and his team at the World Bank, who are currently working on better modeling of these interactions (this is still work in progress, with no public documents yet available).

\footnotetext{
${ }^{3}$ This is in close coordination with the implementation of Poverty Reduction Strategy Papers (PRSP), which drive resource allocations within many developing countries. For an interesting overview of the issues raised by PRSPs, see Booth (2003) in his introduction to a special volume of the Development Policy Review on PRSPs.

${ }^{4}$ There is clear recognition of these interactions at the sector level. See, for instance, Ballar and others (2000) and Wang (2002), who examine this issue in the context of the health sector.

${ }^{5}$ The World Bank is generating equivalent snapshots for Africa and a number of Asian countries. But data problems have been so severe that publication of the report keeps being postponed.
} 


\section{Financing for Infrastructure}

The literature on financing issues in infrastructure can be classified in four main groups - even though, in practice, they tend to be closely correlated:

- What are the financing needs of infrastructure?

- How much scope is there for private participation in infrastructure financing?

- How much fiscal space do governments have to meet infrastructure financing needs?

- What should drive the new wave of financing mechanisms?

\section{Financing needs}

Considerable financing is required to meet the demand for infrastructure services in developing countries. But no one really knows how much is needed. There are many "back of the envelope" estimates in political documents, but there is no detailed assessment of global needs from a single source. The best available data are rough estimates of investment needs and operations and maintenance costs for various sectors based on trends or rough demand functions.

The water and energy sectors are probably better off than other sectors. Still, for water the World Health Organization has produced figures (about $\$ 50$ billion a year) that are widely questioned by the academic community because they are based on access rates, unadjusted for differences in quality. For energy the International Energy Agency recently provided estimates for various regions, but these are based on extrapolations from the largest countries. For telecommunications the International Telecommunication Union regularly issues global projections of investment needs, but these inspire enormous debate among specialists. The UN's Habitat generates data on housing and urban service needs, but there is considerable overlap with other estimates, and it is almost impossible to determine the investment needs of various sectors without getting into double-counting problems. To my knowledge, no equivalent data have been generated for the transport sector.

To advance data on financing needs, the World Bank and the UN are working on crosssectoral estimates. Fay and Yepes (2002), expanded in Briceno and others (2004), provide benchmarks for regions and country groups for investment and operations and maintenance needs against which country-specific estimates can be assessed, to inform national debates on resource allocations. Ongoing work by Jeffrey Sachs's UN team is providing a useful reality check for the poorest countries. The estimates that emerge from such work are high. In Sub-Saharan Africa infrastructure investment and operations and maintenance needs are at least 12 cents a day per person, or $\$ 44$ a year - a lot given that more than half of the region lives on less than $\$ 1$ a day.

But this number game is not over, and new country- and region-specific estimates will emerge over the next year or so. Indeed, some regional banks (ADB and IDB) are generating their own estimates as part of the monitoring of the MDGs or as part of a larger debate on the engine of growth and competitiveness. But most of these data have not yet been published.

For illustration purposes, I report here the investment needs estimates of Briceno and others (2004). Electricity, mobile phones, and roads account for four-fifths of projected investment needs in 2005-10 (table 1). These estimates do not account for investment needs in related businesses such as gas transport and distribution or other transport infrastructure such as canals, 
hydraulics, port, airports, and modal integration. Moreover, they assume that investments are used efficiently. Ignoring the important fact that in the telecom sector progress continues to cut costs dramatically, these estimates are thus probably lower bounds of the needs. Moreover, the assumption that investments are used efficiently is a strong assumption for most countries, industrial or developing. ${ }^{6}$

Table 1: Expected annual investment and operations and maintenance needs, 2005-2010 (percentage of GDP)

\begin{tabular}{|l|c|c|c|}
\hline Country group & Investment needs & O\&M needs & Total \\
\hline Low income & $3.5-4.5$ & $4.0-4.5$ & $7.5-9.0$ \\
\hline Middle income & $2.8-3.8$ & $2.7-3.2$ & $5.5-7.0$ \\
\hline $\begin{array}{l}\text { Developing } \\
\text { county average }\end{array}$ & $3.2-4.2$ & $3.3-3.5$ & $6.5-7.7$ \\
\hline
\end{tabular}

Note : These are preliminary estimates, currently being updated.

Source: Briceno and others 2004

The most interesting fact emerging from these rough orders of magnitude is that there are large differences across country income groups, with needs ranging from as much as 9 percent of GDP for low-income countries to 5.5 percent for middle-income countries, with an average of about 7.1 percent for all developing countries. ${ }^{7}$ Combining this fact with the lessons from the growth convergence literature, it is not difficult to see why some academics, some policymakers, and many NGOs make a case for an extra co-financing effort by the international community in favor of the lowest-income countries to ease their catching up and accelerate the reduction in poverty. ${ }^{8}$

\section{Public versus private financing revisited}

During much of the 1990s infrastructure policies in developing countries were based on the assumption that financing was going to be rebalanced from its two traditional sources- the public sector (government or public utilities) and official development assistance-toward a third source: the private sector. Although there was a rebalancing, it did not go as far as many had hoped, particularly in the lowest-income countries and in the poorest regions of middle-income countries. Indeed, during the 1990s the public sector financed 70 percent, the private sector 20-25 percent, and official development assistance 5-10 percent of infrastructure spending. These estimates were

\footnotetext{
${ }^{6}$ There is a quickly growing literature on the need to cut costs and improve efficiency in the delivery of public services in general and in infrastructure in particular. For a recent overview, see Coelli and others (2004) or Kessides (2004).

${ }^{7}$ These are rough estimates

8 Although the lack of good data on investment needs reflects a lack of accountability of international and local communities in terms of the effectiveness of the resources allocated to these sectors and some observers question the size of the request for new funding, raising the concern for whit elephants. In that sense, infrastructure significantly lag behind health and education in terms of possibilities of measuring the effectiveness of aid in improving the fate of the poorest.
} 
first made by DFID (2002) $)^{9}$ and have since been confirmed by World Bank estimates (Briceno and others 2004), but these are all rough estimates simply because needed data are not available.

Most of what is known about the public sector comes from the modest information available in the International Finance Statistics published by the International Monetary Fund (IMF). This source suggests that public spending on infrastructure ranges from 2.1 percent of GDP in upper-middle-income countries to 3.2 percent in low-income countries. ${ }^{10}$ Thanks to a research program managed by Easterly and Serven (2003) on Latin America, we have much better data for that region. The authors show that during the 1990s the public sector in the region cut infrastructure sending, reflecting fiscal adjustment programs and unrealized hopes for a major takeover of infrastructure by the private sector. This fiscal adjustment has generally caused a disproportionate drop in public investment, particularly in infrastructure. Very roughly, infrastructure investment levels today average 40-50 percent of what they were 10-15 years ago - and very little of this drop can be explained by more efficient service delivery. In Brazil, for instance, the reduction in public infrastructure investment during the 1990s equaled 174 percent of the fiscal adjustment. The same story holds for low- and lower-middle-income countries: spending levels are well below estimated needs.

Official development assistance (ODA) has traditionally been the second largest source of infrastructure financing. But with the great hope for a large private sector contribution, ODA started to decline in the 1990s. This drop may have contributed to the decline in infrastructure spending (Briceno and others 2004), but it is not clear by how much because there is no database covering all ODA disbursements per sector. In terms of commitments, the 1990s saw a major drop. For instance, infrastructure commitments from multilateral development banks fell from $\$ 18.0$ billion in 1996 to $\$ 13.5$ billion in 1999 , though by 2002 they had recovered to about $\$ 16.0$ billion. But even at its peak, such financing was too small relative to needs. At this point the best that can be hoped for is a significant countercyclical effect-with ODA at least sufficient to offset swings in private sector contributions, as well as leverage funds from private sources.

The private sector now provides more infrastructure financing than does ODA, but there are no official statistics to demonstrate this without a doubt. Research conducted at the World Bank has generated some data on the new contribution of the private sector, but this data is imperfect because much of it focuses on commitments rather than disbursements. Knowing that many signed projects are cancelled before they are implemented, the gap between commitments and disbursement is likely to be high — but no one really knows how high simply because there is no data, again except for Latin America thanks to Easterly and Serven (2003). According to a worldwide database, during 1990-2002 private sector commitments to infrastructure in developing countries totaled $\$ 805$ billion, or $\$ 62$ billion a year. But this average masks enormous fluctuations. Private commitments rose sharply until 1997, then fell quickly in response to East Asia's financial crisis. In recent years they have hovered around levels like those in the mid-1990s. For example, in 2002 private commitments totaled $\$ 47$ billion—the lowest level since 1994. This suggests that private investment accounted for only 10-15 percent of estimated investment needs. In addition, most of these investments have gone to energy and telecommunications (in terms of sectors) and to Latin America, East Asia, and (to a lesser extent) Eastern Europe (in terms of regions).

\footnotetext{
${ }^{9}$ U.K. Department for International Development, 2002, "Making Connections: Infrastructure for Poverty Reduction," London.

${ }^{10}$ The data are only available for a few countries, and in most cases it is not clear whether it reflects just the central government or all government levels.
} 
The partnership with the private sector has not been an easy ride, inspiring a lot of academic research. Guasch (2004) documents levels and sources of contract renegotiation, showing that in Latin America about half of contracts are renegotiated-and for transport and water projects the proportions of renegotiated contracts are significantly higher. Gomez-Ibanez (2003) complements this work with detailed case studies that provide in depth analysis of many of these crisis, while Laffont (2004) provides theoretical support to their analyses of the drivers of renegotiation.

One of the main conclusions of this research is that at some point the success of private participation in infrastructure and the size of the residual public sector responsibility boil down to the cost of doing business in developing countries. This outcome is consistent with the fact that this cost has been much higher than expected. Estache and Pinglo (2004) document differences in the cost of capital across regions, arguing that some sectors and regions have not been and for a while will not be profitable for private investors (explaining the preference for management or affermage contracts over concession contracts or privatization in many sectors). This is also the impression expressed by Ramamurti and Doh (2004), who expect infrastructure-related foreign direct investment to stabilize at lower levels.

Relevant to ODA is some recent theoretical research trying to model the growth effects of various types of transfers made to finance infrastructure. Chatterjee and others (2003) contrast the effects of a transfer tied to investment in public infrastructure with those of a traditional pure transfer. They show that pure transfers have no growth or dynamic consequences but are always welfare improving. That is not the case for transfers tied to infrastructure, where long-run growth and welfare effects depend on the initial stock of infrastructure as well as cofinancing arrangements. The y also show that a temporary pure transfer has only modest short-run growth effects and leads to a permanent deterioration in the current account, while a productive (i.e. infrastructure related) transfer has significant impacts on short-run growth, leading to permanent improvements in key economic variables including the current account. Although these results need to be confirmed empirically, they provide food for thought on the optimal allocation of scarce international resources in developing countries because they suggest that there are useful economic criteria (in contrast to political) to maximize aid effectiveness in infrastructure.

\section{The fiscal space debate}

The latest major debate among policymakers is on the importance of the design of macroeconomic fiscal adjustment programs for the level of investments in infrastructure. Standard fiscal rules adopted to ensure debt sustainability as part of macroeconomic adjustment programs are increasingly being criticized as excessively binding constraints on appropriate countercyclical action. Moreover, there is widespread concern that these rules may permanently reduce the public sector's contribution to capital accumulation, particularly in infrastructure. For instance, compression of public investment in infrastructure can be, and has been, associated under a wide range of circumstances with lower economic growth and less efficient poverty alleviation, which in turn has ended fueling fiscal insolvency which the main concern expenditure cuts were supposed to address.

While this debate has been quite intense in Europe as part of the assessment of the Stability Pact (see Turrini, Buiter, and Graf for overviews), it is new in developing countries in the context of the search for an increased role of the private sector in the financing of the infrastructure sector. Raised in a book edited by Easterly and Serven in 2003, it has now gone mainstream in the policy 
arena. The Brazilian and Pakistani heads of state have both mentioned during 2004 the need to find alternative solutions to fiscal adjustment that does not penalize infrastructure projects, while recognizing that the new rules would have to avoid white elephants.

The debate can be summarized as follows. Standard IMF adjustment programs want to make sure that public expenditures, including sectoral allocations of expenditures, are consistent with the short-term liquidity constraint faced by a country, the short-term aggregate balance (no inflationary pressure due to excess demand), medium-term debt sustainability, the need to avoid endorsing excessively costly or inefficient levels of public expenditures, and the promotion of private participation in infrastructure.

While general principles seem to be agreeable to all parties, there is some disagreement on how to address each of these concerns because there is no agreement on the specific measures to consider. For each of these concerns, there is some scope for sensitivity analysis. There is concern that the liquidity constraint gives a lower bound for all the expenditure levels to consider rather than a precise indicator. While this is a useful indicator, it needs to be complemented by an assessment of an upper bound. This upper bound comes from three sources: (i) the definition of liquidity (see Easterly and Serven 2003 for illustrations of this for Latin America), (ii) the time horizon during which this liquidity (whatever the specific concept) needs to be considered and averaged out, and (iii) the level and type of expenditures to be included - that is, Which kind of public enterprises (with or without a hard budget constraint)? Should public enterprises be outside the budget, as in Chile? Which kind of projects? Which kind of guarantees should be accounted for as expenditures and at what time? Should it be done on a cash or an accrual basis? And should recurrent and capital expenditures not be systematically separated for every sector (à la Blanchard and Giavazzi 2003).

In addition, it seems reasonable to have a better sense of the relevance of the level, origin and timing of the financing sources for the assessment of the desirability of infrastructure investment in view of the fact that this has been one of the most creative areas in infrastructure policy over the last 10-15 years. The basic question that need to answered include: Which kind of financing sources, fiscal or quasi fiscal expenditures, need to be covered? Do the sources matter (international financial institutions and bilateral donors are fine, but others are more risky)? When are guarantees a quasi fiscal deficit? What share of private participation throws the project off balance, and will this choice lead to cream skimming in the design of projects? Should it be driven by risk sharing levels or by something else?

There are many more related technical issues, but they go beyond the scope of this paper. One, however, deserves to be highlighted. What needs to be recognized in estimates of the fiscal space is that solvency is by definition an intertemporal concept. Indeed, solvency has to rely on the present value of both assets and liabilities. Many academics have pointed out that it does not seem correct to assess the strength of fiscal accounts only from the time path of gross financial liabilities. (For an economic discussion see Ballasone and Franco 2000; Blanchard and Giavazzi 2003; Buiter and Grafe 2004; or Turrini 2004. For an accounting viewpoint, see McCrae and Aiken 2000.)

Of particular interest in this context is the fact that infrastructure has an unusual cash flow, with high short-term costs and high long-term returns. Standard fiscal accounting ignores this and introduces a bias against any project with a cash-flow stream that is initially negative, with costs incurred in the present but returns accruing only over time. This bias leads to excessive compression of investment (CAPEX) as well as operation and maintenance expenditures (OPEX), 
particularly during the transition toward a deficit target, and can be most damaging for expenditures that help enhance future growth. Indeed, any analysis of infrastructure needs to distinguish between recurrent and capital expenditures and rate them according to their contribution to the growth and social agenda. These two are linked, but their relative importance varies significantly across sectors. Yet cuts tend to be across the board-with brutal (including regressive) distributional consequences (see Calderon and Chong 2004).

But this is not only an accounting problem. Over the past 20 years political decisionmaking has replaced economic criteria in determining the allocation of resources in developing countries. Indeed, 20 years ago all the multilateral development institutions had their own manual of economic cost-benefit analysis that was supposed to be used as part of annual public expenditure reviews. These reviews were supposed to guide the allocation of resources, and cuts were easy to implement since they were a decreasing function of rates of return. The changes in the resource allocation process over the past 20 years have resulted not only in less investment (to a large extent because its lower profile in the ODA agenda), but also in much more imbalance in the allocation of public resources between OPEX and CAPEX. This is having long-term consequences for growth (Reinikka and Svensson 2002; Rioja 2003a, b; Kalaitzidakis and Kalyvitis 2004).

For instance, Riojas (2003b) shows that reallocating funds from new infrastructure to OPEX can have positive effects on countries' GDP. In addition, Kalaitzidakis and Kalyvitis (2004) provide a useful framework to see what would happen if infrastructure resources were allocated more rationally. Relying on an infrastructure-led growth model where the durability of public capital is endogenous and varies according to its usage and the level of maintenance expenditure, changes in total expenditures and the maintenance share are shown to be important for the steady state and the dynamic behavior of the economy.

Following a recent IMF board discussion (April 2004), the IMF and the Bank have begun to explore these issues in a number of pilot countries, with a view to assessing the room to increase the fiscal space for productive public investments, particularly infrastructure. For these pilot countries the Bank and the IMF are working on how the principles can be put into practice, focusing on defining the appropriate balance between productive investment and fiscal prudence, exempting commercially run public enterprises from fiscal targets, and better measuring and managing public sector liabilities incurred in public-private partnerships.

\section{The search for new financing mechanisms}

On the one hand, the expectations in the early 1990s of strong prospects for private participation in infrastructure have not been realized - and given the estimates in Estache and Pinglo (2004), there are few reasons to expect that in some sectors (such as water and rail) and regions (such as lowincome countries) the prospects will improve significantly under current arrangements. On the other hand, the needs are so large that it is crucial for the international community to come up with creative ways of leveraging resources from all sources.

Despite the importance of these needs and the relevance of the design of risk allocation mechanisms in resolving this apparent inconsistency, there is little infrastructure-specific literature on this topic. Within the more general literature there are four main directions in which academics and international organizations seem to be going. The first is a technical literature on the desirability and conditions of efficient public-private partnerships. The second is a large literature on the need to develop financial markets in the developing world. The third is a search for new 
and improved risk mitigation products that will help strengthen the connection between infrastructure development and private financial markets. The fourth deals with subsovereign issues, recognizing that over the past 10-15 years there has been unprecedented political and fiscal decentralization around the world (discussed below). In many countries local populations elect subsovereign officials and subsovereign governments become responsible for delivering infrastructure services. In that context the capability of local authorities and institutions to attract resources becomes crucial, and the academic literature is starting to cover this issue.

The theoretical literature on the scope for public-private partnerships is quite large and has filled many pages of some of the most technical journals in economics. Laffont and Tirole (1993) catalyzed this literature, but see also Armstrong and Sappington (forthcoming), Bos (1994, 2003), Hart (2003), Newberry (2000), and Laffont (2000). Just before his death in May 2004, Professor Laffont finished a manuscript updating much of that work, with a focus on developing countries and an emphasis on infrastructure (Laffont 2004).

The main lesson of this literature is that regulators must arbitrate between risk levels and their distribution, the efficiency levels that can be achieved in infrastructure, and the rents that remain with operators. In other words, to be viable, a financing mechanism and a regulatory regime may need to rely on a risk allocation that does not yield the most efficient outcome in service delivery. This means, for instance, that when risk levels are perceived to be very high, rate of return regulation may be more effective at attracting private capital than a price cap regime. More generally, this literature argues that the characteristics of developing countries should often lead to recommendations quite different from those that would be given for infrastructure restructuring in industrial countries. Indeed, the limited enforcement capabilities in developing countries are significant in practice and, along with unusually high risk levels, are one of the main reasons one size does not fit all when reforming infrastructure. This literature also hints at the relevance of many other institutional issues, including the relevance of the degree of capital market development, as discussed next.

The second set of research has tended to focus on issues associated with the degree of development of local financial markets. It is quite wide, and to some extent beyond the scope of this paper. It typically deals with more than just the financing needs of infrastructure (see Bortolotti and Siniscalco 2004 for a recent survey on the world experience and von Hirshausen 2002 for an insightful discussion of the interactions between institutional development and infrastructure reform in Eastern Europe). The main message is simple: institutions matter, and this message is now the bread and butter of many aid agencies. For instance, the World Bank is sponsoring numerous projects focused on institution building (economic regulation, judicial reform, conflict resolution, and so on) to allow financial markets to fund infrastructure development.

The third area of research focuses on the optimal distribution of risks between the players in the financing game and involves the development of innovative risk mitigation products and applications to foster private capital mobilization for infrastructure development (see Esty 2004 for a wide review and Irwin 2003 for a more direct application to infrastructure). The literature offers four main lessons to policymakers. From a strictly financial viewpoint, the financial structure matters-and in ways that are quite relevant to the design of financing strategies in developing countries. Of particular interest is the importance of the governance structure associated with the financing of infrastructure projects, as documented in a survey by Becht and others (2003). Second, in more general terms, this literature shows how improved risk allocation mechanisms addressing currency risks and regulatory risks can help reduce uncertainties faced by 
private investors assuming infrastructure-related risks (Marrison 2001). Third, credit providers can gain from coordination to reduce everyone's risks levels when capital markets are imperfect (Estache and Kartacheva 2003). Finally, related to this literature with important implications for infrastructure is a growing body of research demonstrating the importance of auditing and the limits of creativity in financial designs when financial accountability is limited (see Legros and Iossa 2004).

The final area of research reflects the fact that a large part of infrastructure development takes place at the subsovereign level, with subsovereign entities responsible for the provision of public services (see Freire and Peterson 2004 for an overview). Fiscal capacity is a major issue when it comes to financing subnational investment needs (see Lewis 2003 on Indonesia, for instance), and hence supporting the transition of these entities from sole central government funding to market-based funding where they can also access private financial markets for their needs is critical to mobilizing additional private capital for infrastructure services. The main lesson of this literature is that new instruments will have to do better in terms of generating the appropriate credit enhancement to achieve creditworthiness at the project level and often at the local government level.

\section{Urban versus Rural Infrastructure Needs}

A large share of the literature on poverty is focused on the rural versus urban poverty debate. It shows that even though urban and rural poor people have much in common, there are some important distinctions-especially when it comes to infrastructure. ${ }^{11}$ Because rural poor people live in relatively low-density areas and rely heavily on natural resource-based production, their demands for infrastructure are quite different from those of the urban poor. ${ }^{12}$ Both groups tend to have limited access to public infrastructure and services, but the constraints on physical access to job and product markets are bigger concerns for the rural poor (see the case studies by Fan and his various co-authors or van de Walle and Cratty 2004 for recent detailed studies). At the same time, access to network utilities is less important because many of the rural poor prefer more costeffective local solutions for their reeds_-such as solar energy, water pumps, and satellite-based telecommunications. In the context of urbanization, the growth of megacities is fast becoming a major source of demands for additional infrastructure, creating a sense of urgency in some policy circles. ${ }^{13}$ But this is criticized by some academics as favoring excessive urban concentration (see Vernon 2002). New infrastructure also creates additional incentives for rural urban migration .

These differences in concerns have a long history in the academic literature, and there is not much news to report in this area. But new debates in policy circles are also starting to make

\footnotetext{
11 The minimum population threshold for defining urban areas varies dramatically among countries, but "urban" is typically characterized by density of settlement in a contiguously built-up area, by the structure of economic activity, and sometimes by administrative attributes.

${ }^{12}$ Diversification of income sources is a key component of rural poverty reduction strategies, and one that depends on infrastructure to be effective (see Ellis 1998 for a survey). In a survey of the literature identifying a poverty trap similar to the one observed in regions with large rural populations, as in Africa, Booth (2004) lists eight factors used by all authors to explain poverty that is mostly rural in those regions. One is poor land and sea transport infrastructure, which makes market development unusually difficult. Fan and others. (2004a, b, c) provide impressive evidence on the various channels through which infrastructure contributes to poverty reduction and show how different these channels can be across as well as within countries.

${ }^{13}$ There are more than 400 cities with a population of over 1 million-up from 16 cities 100 years ago.
} 
their way into the research world. I will focus here on a single question recurring in policy circles: is there a dominating bias in favor of working on the alleviation of rural poverty rather than urban poverty? ${ }^{14}$ Is the story the same across sectors (i.e. Water vs. energy vs. telecoms vs. transport)? Are the needs of tomorrow's poor well anticipated? Are tomorrow's poor likely to be mostly urban?

There is plenty of evidence showing that poor people urbanize faster than the population as a whole, which implies that anticipating their needs will require a stronger focus on urban issues. ${ }^{15}$ Yet in many regions, the sheer numbers argue otherwise. In Africa, for instance, more than two-thirds of the population remains rural, and it will likely be a while until the urban population becomes the majority. More generally, experiences across countries suggest that a majority of poor people will still live in rural areas long after most people in the developing world live in urban areas (Ravallion 2002). So, if there were a rural bias, would it not be rational?

This is not a new debate. Almost 30 years ago, Lipton (1977) and Mellor (1976) were concerned with the opposite question: was the urban bias of the international community rational? Ultimately, the choice of the priority is an empirical question (Reardon 2001; Sahn and others 2003). In some regions, such as Africa, rural infrastructure needs are likely to continue to drive the agenda (Mwabu and Thornbecke 2004). In others, such as many parts of Latin America and Asia, urban needs should take priority. Since the priority is an empirical matter, sector-specific poverty data on access for various income groups are needed-but are not available for most developing countries. There are reasonably good databases on the number of poor (although the measurement of poverty continues to be a source of conflict), but no database tells policymakers exactly what the poor are poor in. And even for countries with some data, problems exist.

From a sectoral viewpoint, Living Standard Measurement Surveys (LSMS), Demographic and Health Surveys (DHS), and household consumption surveys raise three types of problems. ${ }^{16}$ First, the fact that they do not generate data for every country trying to get access to international aid aimed at reducing poverty limits the ability of the international community to monitor progress across countries. Second, the questionnaires in the available surveys are seldom comparable, and hence cross-country comparisons and performance benchmarking are quite approximate for many of the variables of interest to policymakers, particularly for infrastructure services. Third, there are significant differences in the quality of the data available for urban and rural areas. The World Bank has started working on standardized questionnaires, but there is still a long way to go.

Ignoring for a moment the data issues, there are some fundamental questions that have not been addressed by researchers. How consistent are the ideal strategies implicit in these differentiated needs assessments for the rural and urban poor with the strategies to maximize the

\footnotetext{
${ }^{14}$ Many in the water community would argue against this, at least form the viewpoint of their sector. According to WHO statistics, for developing regions, rural areas have 5.3 times more unserved people for water supply and 3.6 times more unserved for sanitation compared with urban areas (WHO (2004)). This service gap is not really well correlated with the direction of the lending program of many donors. For instance, in the World Bank's lending portfolio between 1900 and 2001, urban areas received nearly six times more in loan funds than rural areas and this is not explained by unit cost differences. According to the World Bank Evaluation Department (OED), each dollar spent on a rural water system provides approximately four times the population coverage offered by an equivalent urban investment, implying that an urban bias in this case prevails. I am grateful to J. Narkevic for this important footnote.

${ }^{15}$ See Ravallion (2002) and Cohen (2004) for a discussion of population trends.

${ }^{16}$ See also Sahn and Stifel (2004) for an interesting discussion of data issues in the African context and Sahn and others (2003) for a more general discussion that is directly relevant to assessments of the relative importance of infrastructure in the poor people's expenditure patterns.
} 
odds of meeting the MDGs? Will the urban or the rural poor benefit more from the concern for meeting the MDGs? Where is the poverty reduction or MDG payoff from an additional dollar of investment the highest: in highly dispersed rural populations or in highly concentrated urban or periurban populations? There are clear tradeoffs depending on the cost of technology (low unit costs in rural areas versus low average costs from economies of scale in urban areas). The odds suggest that, in the absence of a disaggregation between rural and urban needs across the MDGs, cost-effectiveness in achieving the m may imply that rural poverty reduction will not get the priority it deserves. On the other hand, the focus on the MDGs may hurt the urban poor in a different way. The distinction between the persistently and transiently poor is quite relevant in practice but not equally relevant to the urban versus rural poor. Yet the MDGs do not make this distinction and tend to focus on the persistently poor, which favors the rural poor. This implies that strategies designed to accelerate growth to achieve the desired reduction in an overall index of poverty may be better than those that benefit the persistently poor (Gaiha 2003).

\section{Decentralization (and participation)}

Decentralization has many definitions in the economic literature, as it does in the real world. Most of these refer to administrative or political changes that give subnational governments more authority or responsibility in delivering public services. Since the 1970s many countriesparticularly developing countries-have seen a major increase in decentralization. There is a tremendous amount of economic research on the topic in general, but an amazingly modest amount in terms of its implications for infrastructure. That does not mean that the international community knows nothing about how decentralization affects infrastructure. In fact, there is a lot of useful institutional information on the forms of decentralization around the world and on the various ways that subnational governments organize themselves to finance and deliver local public services (see, for instance, Serageldin and others 2000).

But there is not much empirical evidence on the relative efficiency of the various delivery modes and types for infrastructure, especially in developing countries (see Shah and others 2004 for a recent survey). ${ }^{18}$ In a volume of background papers to the World Bank's World Development Report 1994, on infrastructure, Estache (1995) started this line of empirical research on the levels and effects of infrastructure decentralization. In that volume, Estache and Sinha (1995) show that for a sample of 10 industrial and 10 developing countries, decentralization tends to increase total and subnational spending on infrastructure much more in developing than in industrial countries. This different response has been confirmed by other empirical studies (again, see Shah and others 2004 for a survey). Similarly, the increased demand for infrastructure services caused by decentralization has been confirmed by Faguet (2003). He shows that in Bolivia decentralization has led to rerankings of investment programs in favor of agriculture, education, and water and sanitation.

\footnotetext{
17 The original baseline poverty estimates used for the MDGs were based on income and consumption distribution surveys for 44 countries containing 71 percent of the population in 1990 (Ghaiha 2003). These countries accounted for about a quarter of those considered to be developing. Ghaiha also documents the many sources of data and their inconsistencies.

18 There is a large public administration literature documenting the impacts of various forms of public service decentralization in developing countries. There is also quite a bit of analysis of decentralized health and education services, recently reviewed in the World Bank's World Development Report 2003.
} 
There is also a growing (and mostly still unpublished) literature trying to formalize the empirical results and generate models that explicitly recognize the institutional differences between developing and industrial countries to refine the empirical analysis. Bardhan and Mookherjee (2000a, 2000b, 2003) have offered some of the most influential papers on the topic, highlighting the role of local corruption in the effectiveness of public service decentralization. Their main contributions can be summarized as follows. First, they develop simple analytical frameworks to compare the key dimensions of effectiveness (cost of delivery, accountability and financing mechanisms) of centralized and decentralized delivery systems for infrastructure services, identifying winners and losers and gains and losses from switches between centralization and various forms of decentralization. Second, they show the different ways that local corruption and weak local management skills can influence the cost-effectiveness of decentralization. Their intuition on the need for accountability echoes the less conceptual literature on the subject-for the water sector, see Mody (2004) and Walker (1999). Third, they show that under fairly mild assumptions, decentralization financed by user fees rather than local taxes or intergovernmental grants is superior no matter how poorly local democracy works. More important, if user fees are not used, the superiority of decentralized over centralized service provision is no longer as clearcut as many policy advisers seem to believe when corruption is explicitly taken into account. Finally, the authors show that when ability to pay is constrained and user charges cannot be used to finance antipoverty programs, the optimal degree of decentralization depends on the degree of corruption in local and central governments.

Note that, in many ways as a by-product of the literature on decentralization, there is also a growing literature on the impact of more participatory approaches to service delivery (see Turk, for instance, on how this is playing out in Vietnam). As with decentralization, little of the published economic research focuses on infrastructure services (recent exceptions include Chuwa and others 2002, Keemeier 2002, and Ackerman 2004). Yet efforts to promote participation in projects, programs, and policy consultations are now common in the international community. While there is nothing specific to infrastructure, it is interesting to note that, generally based on qualitative rather than quantitative assessments, ${ }^{19}$ the academic community is starting to be concerned with the implementation of these participatory approaches. These concerns are similar to those raised in the context of decentralization because, as pointed out by Ghazala (2004), not a single study establishes a quantitative causal relationship between any outcome and participatory elements of a community-based development project. Ghazala (2004) and Cornwall (2003) both observe that projects claiming "full participation" and "empowerment" have turned out to be driven by particular interests or elites, leaving the least powerful without voice or much choice. In sum, the poverty reduction effectiveness of these programs needs to be measured more systematically as well. Cornwall (2003) points to the gender bias in participatory projects as a source of concern in this context.

The general concept that increasing the number of players can add to conflicts of interest and increase the difficulty of enforcing accountability is in contrast to what has traditionally been argued by the public finance literature on decentralization. This may be one of the most dramatic changes brought to this policy issue of relevance to infrastructure. The ways that the costs of local public spending are shared between government levels, users, and taxpayers create conflicts of interest between citizens in different jurisdictions similar to those between the various units of the same firm or bureaucracy. Depending on how locally elected legislatures and managers decide on

\footnotetext{
${ }^{19}$ Isham and others (1995) is a notable exception.
} 
spending decisions, excessive spending may result, or resource allocations characterized by uncertainty and misallocation across districts or business units. The extent of the conflict of interest across local units is affected by spillovers and differences in local preferences for the products. In a nutshell, it is all about incentives. The most directly relevant recent papers on this topic include Besley and Coate (2003), Cremer and others (1996), and Poitevin (2000); for a wider discussion of collusion problems in multilayered agencies see Estache and Martimort (2000), Laffont (2000), and Laffont, Faure-Grimaud, and Martimort (2003).

Overall, the main message of this literature is that the sustainability of decentralization and of community-based initiatives depends crucially on an enabling institutional environment. As is better understood than a decade ago, this requires government commitment and much stronger accountability of leaders external to local communities than is available in many developing countries. It also requires better training of the key facilitators and less commitment to the naive application of standard recipes for participation, social capital, and empowerment. Unless these constraints have been fully appreciated, the decision to decentralize has not been fully assessedand often the optimal choice for a developing country will not be the same as for an industrial country.

\section{Targeting, Affordability, and Regulation}

The three topics of this section are closely related. Indeed, in the most general terms, economists define poverty as the inability to afford a specific bundle of goods and services deemed necessary for survival under agreed minimum living standards. This minimum consumption level and its composition may vary across societies or cultures and even across regions within countries, but the idea that there is a minimum does not. Because this minimum is not reached by everyone, governments often consider some form of redistribution from the haves to the have-nots, and this is one of the main concerns in the design of economic regulation. This is the main purpose of targeting.

Infrastructure policymakers tend to target access and affordability separately, relying on different instruments to achieve these goals. For access there are three basic categories of instruments: (i) those requiring operators to provide access (a service obligation to avoid unilateral exclusion by the provider), ${ }^{20}$ (ii) instruments reducing connection costs (through cross-subsidies or direct subsidies built into the tariff design or through credit or discriminatory payment plans in favor of the poor), and (iii) instruments increasing the range of suppliers (to give users choice, including the option of cutting costs by choosing lower-quality service providers).

For affordability, broadly speaking, there are many instruments, but basically they all work in at least one of three ways: (i) by reducing bills for poor households (through lifelines or meanstested subsidies based on socioeconomic characteristics or on the characteristics of the connection and financed through cross-subsidies or direct subsidies built into the tariff design), (ii) by reducing the cost of services (by avoiding granting a monopoly right when it is not necessary or by providing an incentive for operators to reduce costs and pass on the cost reductions to users), and

\footnotetext{
${ }^{20}$ This issue is not addressed in this paper; interested readers should see Chisari and others (2003), Clarke and others (2002), Cremer and others (2001), Gasmi and others (2002), and Laffont (2004)
} 
(iii) by facilitating the payment of bills (by allowing discriminatory administrative arrangements in favor of the permanently or temporarily poor). ${ }^{21}$

For a long time, analysis of these instruments focused on efficiency and was conducted at a fairly theoretical level by public finance specialists. But enormous methodological progress over the past 10-15 years has allowed the academic world to make much better assessments of the performance of these instruments not only in terms of efficiency but also in terms of their effects on the behavior of poor people and service providers. Methodological developments have occurred in three fields: microeconometrics (especially developments in the econometrics of panel data), evaluation techniques, and incentive theory applied to the theory of regulation. The standard reference on microeconometrics is Deaton (1996). A recent book edited by Bourguignon and Pereira (2003) and containing contributions from many of the key researchers in the field provides an exhaustive overview of the status of evaluation techniques. On incentive theory the standard reference is Laffont and Tirole (1993), and for developing countries Laffont's final book (2004) will likely become the main source.

A look at the empirical evidence generated from these theories is somewhat disappointing for infrastructure policymakers. The top academic economic journals contain relatively few specific articles on targeting, affordability, or regulation for infrastructure services in developing countries (especially relative to health and education services, where the re is much more data and data quality lends itself better to academic publications). On targeting - which has received the most attention, and almost invariably raises issues of affordability and regulation--, an unusually large share of the recent output has been generated by a few contributors, including P. Lanjouw, Ravallion, Van de Walle, and Wodon-alone or with coauthors. ${ }^{22}$ The main contribution of this literature has been developing techniques that allow the production of poverty maps and of rigorous analysis of the evolution of poverty and its characteristics over time, making it possibly to identify the effects of various policy instruments used to alleviate poverty. Much of what is known about what works and what does not at the household level is due to these researchers.

Of particular interest to infrastructure policymakers is the effectiveness of targeted subsidies, one of the most common redistribution instruments used to reduce "infrastructure poverty." Despite their popularity in policy circles, particularly for infrastructure, targeted subsidies (as well as safety nets) have long been held in low regard by academics for their alleged ineffectiveness (in terms of economic efficiency and incentive costs). But the verdict delivered by new databases is that in many cases these costs are modest. In other words, direct subsidies and cross-subsidies are not always as bad as they are made out to be. Moreover, these results seem to hold for both temporary and chronic poverty. (For a useful recent review of the debate and survey of the empirical evidence, see Ravallion 2003.)

\footnotetext{
${ }^{21}$ See Estache and others (2004).

22 These publications include Lanjouw and Lanjouw (2001), Lanjouw and Ravallion (1999), Ebers and Lanjouw (2001), Ebers, Lanjouw, and Lanjouw (2003), Lanjouw, Quizon, and Sparrow (2001), Ravallion (1999a, 1999b, 2000, 2003), Ravallion and Lipton (1995), Galasso and Ravallion (2004), Van de Walle (1998a, 1998b, 2000, 2003), Van de Walle and Nead (1995), Wodon (1997), Wodon and Yitzhaki (2002), Duclos, Makdissi and Wodon (2004), Makdissi and Wodon (2004a, 2004b), Wodon, Ajwad and Siaens (2003) and Ajwad and Wodon (2002, and forthcoming). There are also many good pieces of analytical work that rely on these authors' techniques but develop them in a more operational context - which is why they seldom get published. See, for instance, the various working papers by Vivien Foster and her coauthors in the bibliography, which show that these techniques are not simply academic exercises, and can be of utmost relevance to the design of reforms on the ground.
} 
This finding is not news for many infrastructure practitioners. ${ }^{23}$ For water and energy there are minimum consumption levels defined by international organizations and most countries (for example, 20 liters of water per person per day and 10 kilowatt-hours per household per day). ${ }^{24}$ Cross-subsidies are intended to help finance these needs through redistribution. Every "field person" has great success stories on the effectiveness of these cross-subsidies. But there are also any documented experiences where well-intended targeting mechanisms were regressive. ${ }^{25}$ there is indeed evidence that under many common circumstance, even when connection subsidies are typically more important for the poor than consumption subsidies, lifelines are the main instrument and is often set too high.

Developments in evaluation techniques also allow for more systematic assessments of the distributional implications of reforms. A reform can help poor people but be regressive, but it can also be regressive without helping the poor. These issues can now be reliably handled quantitatively. New techniques allow identification and monitoring of the most vulnerable groups with respect to reforms, as well as good evaluations of the relative and nominal impacts of reforms. But this literature provides much more than ex post assessments of policy reforms. It makes the case for systematic monitoring of the effects of new reforms and projects to ensure that they internalize lessons of the past. This can be done at the project level (see Baker 2003 and Duflo 2003 for surveys) or at the macroeconomic level. This can be important when micro household data are weak or interactions with other sectors need to be assessed.

A macroeconomic assessment of infrastructure's importance for poor people is needed because in most cases water, energy, telecom, and transport reforms have an impact on other markets (such as the labor market and investment savings market) that matter to the poor. These feedback effects are potentially significant for poverty alleviation, and an economywide analysis is needed. This usually calls for a multiagent, multicommodity model. Computable general equilibrium (CGE) models are increasingly becoming a useful analytical response to these needs.

CGE models simulate economic and social impacts of reforms and are based on the socioeconomic structure of a social accounting matrix (SAM), with its multisectoral disaggregation. The basic idea behind a SAM is to identify the linkages in an economic system. The basic elements when constructing a SAM are input-output tables combined with government accounts and household surveys. The household surveys are crucial for performing impact analysis on welfare and poverty. How deep the analysis can go depends on data availability. The CGE literature on the effects of public infrastructure service reform is rather modest: Chisari and his colleagues (1999, 2003) and Navajas (2000) for Argentina, Andersen and Faris (2002) for natural gas in Bolivia, and Logren and others (1997) for rural Morocco. Their main contribution is to show the importance of infrastructure for achieving the MDGs and, maybe most important, to show that good regulation is redistributive and progressive.

These new results from theory and econometric analysis have generated intense international debates. In fact, analysis of poverty targeting to ensure access to affordable minimum infrastructure services for poor people and of associated regulatory needs is probably one of the two fastest growing "business lines" for international donors, think tanks, and NGOs working on

\footnotetext{
${ }^{23}$ See Foster and others (2000a, 2000b, 2003, 2004) or Gomez-Lobo and Contreras (2003) for examples.

${ }^{24}$ In addition, in developing countries the rules of thumb are that households should not spend more than 5 percent of their income on water and sanitation and more than 5-10 percent on energy (depending on the region).

${ }^{25}$ Estache, Foster, and Wodon (2002) show how common this is in Latin America.
} 
infrastructure. (The other fast-growing area is the link between infrastructure and corruption). In just the past three years international organizations, bilateral agencies, and think tanks have produced five major books on how infrastructure reforms affect poor people (Estache and others 2002 on Latin America for the World Bank, Ugaz and Waddams-Price 2003 on Latin American and European experiences for the United Nations, Brook and Irwin 2003 on the world experience for the U.K. Department for International Development and the World Bank, Kessides 2004 for the World Bank, and Nellis and Birdsall 2004 on the world experience for the Center for Global Development, an influential U.S. think tank). ${ }^{26}$ The Inter-American Development Bank also plans to release such a volume (Chong and Lopez de Silanes forthcoming).

All these books touch on targeting, affordability, and regulation to some degree. Most provide peer-reviewed case studies documenting — with varying degrees of technical refinementthe impact of sector reforms on at least one of these three policy issues (as well as many others, including changes in fiscal costs or operator profitability). Kessides (2004) is a survey of previous studies. Estache and others (2002) is more methodological and describes how to design targeting, and provides many examples of the use of these methods to assess the effectiveness of past reforms. It provides a bridge between the more theoretical developments offered by the academic literature.

The main message of these books is that the reforms of the 1990s have generally increased the efficiency of infrastructure sectors but that these efficiency gains have not always been shared with users, particularly the poor. The six main reasons the poor have not always benefited are:

- When tariffs were redesigned to be more efficient, they sometimes became less progressive or more regressive (or both) than before the reform (such as when countries eliminated crosssubsidies).

- Major increases in indirect tax rates-which tend to be more regressive-were applied to reformed infrastructure sectors to allow the state to capture part of the rent generated by efficiency gains.

- Operators increased enforcement of revenue collections.

- Increases in quality made services unaffordable for some users.

- Cream-skimming in the design of restructuring eliminated cross-regional subsidies and so slowed investment programs in the poorest regions when governments could not compensate through increased subsidies.

- $\quad$ Failures to alleviate credit rationing added to the difficulties of financing poor users' expansion needs.

\footnotetext{
${ }^{26}$ These institutions have also generated a huge number of unpublished studies and working papers, some of which are available on their Websites. There are too many to do them justice in this paper.
} 


\section{Corruption}

This section summarizes the literature on four policy issues related to corruption: its level in infrastructure, its effects, its drivers, and what can done about it. ${ }^{27}$

\section{The level of corruption in infrastructure}

Favoritism, fraud, cronyism, patronage, embezzlement, bribes, and state capture are all concepts that have long been associated with the delivery of infrastructure services in many countries. In the early 1990s their perceived increase in the sector was, in many countries, one of the arguments used to motivate privatization. Ten to fifteen years and many reforms later, the same concerns are reemerging in discussions about the delivery of infrastructure services. Indeed, the level of corruption in the sector is one of the main concerns for policymakers and opinion-makers monitoring service delivery in developing countries. The main debate has shifted from the interactions between public operators and users to those between private operators and government. NGOs are releasing books expressing concerns about the issue (such as Finger and Allouche 2002 and Hall and Lobina 2002), documenting legal events that have demonstrated incidents of corruption in the sector. (Friends of the Earth 2001 and social scientists express concerns about the unusually high costs of renegotiations in the sector, while Flyvberg and others 2002, 2003a, 2003b and Mitlin 2002 point to their surprising high levels; see Guasch 2004.)

The most powerful recent indicator of the importance of this issue may be that one of the main watchdogs in the business, Transparency International, has just released a survey of corruption and privatization in infrastructure in developing countries (Boehm and Polanco 2003). Unfortunately, this survey provides little new quantitative evidence and only covers concepts and useful anecdotes. Indeed, there is little applied or even theoretical research on this topic-maybe because there is even less data available than for all the other topics covered in this survey.

With the exception of a database compiled by Clarke and Xu (2003) for Eastern Europe and some sense of the ranking of utilities among corrupt institutions from the Global Corruption Report (2004), to my knowledge the annual Global Competitiveness Report provides the only comparable, quantitative, multicountry (59 developing countries) overview of corruption in infrastructure sectors, ranking countries according to the perceived degree of corruption (based on interviews with private firms), among many other criteria. ${ }^{28}$ Aggregating the country-specific results by country income group and focusing on the two questions relevant to infrastructure yields sobering results in the report's 2002-03 edition:

\footnotetext{
27 There is an extensive literature on how to define corruption and on the semantic practices of different institutions; a helpful recent survey is Lanyi (2004). For a recent survey on economic analysis of corruption, see Aidt (2003); on levels of corruption, see Kaufmann and others (2003).

${ }^{28}$ There are also country-specific databases dealing with publics services, but these are the exception rather than the rule (see Reinikka and Svensson 2002, Svensson 2003, and many of the country reports from Transparency International available on its Website).
} 
Question 7.02: In your industry, how commonly would you estimate that firms make undocumented extra payments or bribes connected with getting connected to public utilities? $1=$ common, 7 = it never occurs.

The average rating by income groups is:

○ High-income countries: 6.30

○ Upper-middle-income countries: 5.33

○ Lower-middle-income countries: 4.59

○ Low-income countries: 3.33

Question 7.04: In your industry, how commonly would you estimate that firms make undocumented extra payments or bribes connected with public contracts? $1=$ common, $7=$ it never occurs.

The average rating by income groups is:

○ High-income countries: 5.42

○ Upper-middle-income countries: 3.93

○ Lower- middle-income countries: 3.58

○ Low-income countries: 2.83

These responses suggest that the poorer a country is, the bigger is the perceived corruption problem in infrastructure. The presentation of the data, however, poses a few problems. One is that for confidentiality reasons the data cannot be presented at the sector level-because in many countries infrastructure service providers are monopolies, and reporting what the sector thinks about corruption would boil down to reporting what the firm thinks. But the main problem with this data is that it is based (as most international databases are) on executive surveys. Though useful, this approach tells us little about what the government thinks about corruption. And, more important in this context, it tells us nothing about how poor people see the problem. Unfortunately, the few surveys polling large numbers of people around the world (such as Gallup International) do not cover infrastructure services. ${ }^{29}$

\section{The effects of corruption in infrastructure}

While there are many publications on how corruption affects growth, foreign direct investment, trade, and public sector finances, there is little evidence on how it affects infrastructure performance. Most of the existing evidence is for utilities. In recent years I have come across just six publications analytically assessing the impact of corruption on infrastructure services: Davis (2003) on South Asia; Lovei (1998), Lovei and McKenchie (2000), and Clarke and Wu (2004) on Eastern Europe; Rossi and del Bo (2004) on Latin America; and Estache and Kouassi (2002) on Africa. The first four papers are direct assessments and the last two indirect (through regressions) of the efficiency performance of the operators. There are also a number of surveys collected by countries and donor agencies, but these are not widely available. Other publications of relevance

\footnotetext{
${ }^{29}$ A notable exception is Latinbarometro for Latin America, which conducts a regular "confidence vote" survey on privatized utilities that includes questions about corruption. The detailed data from these surveys are not available to the research community, however.
} 
are Reinikka and Svensson (2002), which shows that corruption damages the performance of public services; and Svensson (2003), which shows that the lower the competition, the higher the bribes paid to public officials.

Clearly, a lot more work needs to be done. The additional work is particularly important because there seems to be evidence from the more general empirical literature that occasionally corruption has had unexpected effects. Ignoring the crucial ethic issues, while some of the econometric studies shows the damage done by corruption in general in the sector, some also shows that under very specific circumstance, it has positive effects on some performance indicators. For instance, Mauro (1997) and Tanzi and Davoodi (1997) find opposite signs on the effect of corruption on public spending: Mauro argues that it raises it, while Tanzi and Davoodi argue that it lowers it. Both results could easily be justified and consistent with different samples. Corruption may raise unit costs and hence increase spending for a given set of projects. But under budget constraints this may reduce the number of projects-and because projects are lumpy, it may ultimately decrease spending in the sector.

Another puzzling finding comes from Rock and Bonnett (2004). They show that while in most regions corruption has the expected negative effects, in large East Asian countries with governments with long time horizons, corruption has had positive short- to medium-term effects on growth thanks to collusion between governments and their big business partners. But Rock and Bennett also point out that it is not clear that the investment choices associated with corruption in these countries are the right ones for long-term growth since they cater to the preferences of local businesses.

Laffont and Meleu (1999) and Laffont (2004) provide another puzzling story on the effects of corruption. They point to a Ushaped effect of corruption on the privatization rate in Africa. That is, up to a point, corruption facilitates privatization-but eventually it hurts it. This finding needs to be contrasted with the fact that in a recent survey, corruption was considered the biggest obstacle to doing business in the region (reported in Nwanko and Richards 2001). There are obviously many things that we do not understand about the interactions between infrastructure performance and corruption. Finally, Celentani, Ganunza, and Peydros (2004) develop a model consistent with the fact that an increase in competition in international business transactions can have the perverse effect of increasing corruption. They then show how the design of international conventions influences the effectiveness of the fight against corruption.

\section{The drivers of corruption in infrastructure}

Developments in the theory of incentives over the past 20-30 years have changed how we look at institutions. We can now model the nonbenevolent behavior of all agents (users, operators, and governments). We can also model the heterogeneity of governments (horizontal and vertical separation of functions and responsibilities) and users (rich versus poor). This has generated an enormous literature that cannot be reviewed here but is synthesized in Laffont and Martimort (2001).

In a nutshell, what this literature does is model the "simple" situation where an economic actor (the principal) delegates a task to one or more economic actors (the agents). The relationship is seen as a contract, and each actor has information that only they know and that they use to improve their well being. The main message is that the challenge is to determine what drives incentives to cheat. This requires ensuring that the agents are what they appear to be (in

infrastructure, for example, this means checking whether the prequalification of bidders on public 
contracts or privatizations is working well) and that their efforts are consistent with contractual expectations (in infrastructure this means checking whether the contract is enforced and enforceable). Moreover, when there are multiple agents (say, various electricity distribution companies or telecom operators) or principals (an environment regulator and water regulator in addition to the public works minister and the environment minister), these theoretical developments show how fast the opportunities for corruption get multiplied. Bardhan and Mookherjee (2000a, 2000b and 2003) show how corruption changes the optimal degree of decentralization and financing of public services according to the location of corruption in the economy and the associated incentives. All this points to a major theoretical case for monitoring, auditing, and associated penalty systems that is slowly but surely going mainstream in the academic literature (see Faure-Grimaud, Laffont, and Martimort 1999, Armstrong and Rochet 1999, or Khalil and Lawarree 2001 for examples directly relevant to the regulation of monopolies), but that still has a long way to go to address many of the peculiar issues of the infrastructure sector.

To be bring the discussion down to earth, in addition to the usual explanation of low wages in the public sector, two important features of infrastructure drive incentives: projects tend to be bigger than in other sectors, and services are often granted with a monopoly on delivery as well as over control of the information needed to ensure that there is no abuse by the monopoly. But this is not just a theoretical conjecture. Flyvbjerg and various colleagues (2002, 2003a, 2003b) have undertaken an extensive review of transport projects (mostly in industrial countries but with a few in developing countries) and conclude that rail and road projects consistently exceed their costs and overestimate their usage forecasts. Their main point is that current procurement rules give bidders an incentive to announce low costs to increase their chances of winning projects, then renegotiate. The authors recommend reforming planning processes to get incentives right and to make information more transparent and better audited. Similar concerns are expressed by Guasch (2004).

The most analytically encompassing paper on sources of corruption in infrastructure is Clarke and Xhu (2004). They show that for 21 Eastern European countries, bribe takers (utility employees) are more likely to take bribes in countries with greater constraints on utility capacity, lower competition among utilities, and state ownership of utilities. Bribe payers (enterprises) are more likely to pay bribes when they are more profitable, have greater overdue payments to utilities, and are de novo private firms. Much more work of this type needs to be done to rank the policy issues in addressing the fight against corruption.

\section{How to address corruption in infrastructure}

Again, because the literature is so large, it is impossible to do justice to all its dimensions and authors. Thus I will focus on two solutions argued for in the literature that have had some important effects on infrastructure policymakers: privatization and regulation.

Privatization. The main case for privatization emerges from the modeling of corruption as the nonbenevolence of government, starting with Shapiro and Willig (1990), Shleifer and Vishny (1994), and Boycko, Shleifer, and Vishny (1996). Assuming that it is easier for corrupt politicians to control public firms than private firms, these researchers develop a set of models making the case that to reduce the control government has over the rent a sector can generate, privatization is necessary. In other words, privatization is good if it makes political interference more costly. 
Thus, to reduce corruption, reforms must increase its political cost. But there is growing evidence that this solution has not worked equally well in all regions and all sectors. In the context of infrastructure privatization, corruption problems have come up at the prequalification stage, the bidding stage, and the contract level-particularly in water and road contracts, much less so in energy and telecom contracts (Guasch 2004).

Regulation. Once privatization or restructuring (ownership is not the issue now) has been implemented, enforcement mechanisms are the main instruments available to ensure that operators have incentives to deliver services. There is reasonable consensus between practitioners and theorists on many of the issues covered here. The main message from the literature can be summarized as follows. Everyone seems to agree that utility regulation must promote (static and dynamic) efficiency while it protects consumers from potential monopolist abuses and investors and operators from political influence. Regulation is also widely seen as crucial because it is essential to ensuring that poor people get their fair share from infrastructure reforms. But regulation needs to be fair and recognize that no single actor can be favored excessively. Excessively redistributive regulation reduces the incentives of the private sector to participate. And everyone agrees that there is a tradeoff between the credibility of regulatory commitments and the flexibility required to rebalance (as needed) the interests of the various actors. (See Laffont and -Martimort (2001) for a more detailed overview.)

Some degree of flexibility is desirable, but the track record of governments in their use of flexibility is generally perceived as having been so problematic that the rules built into various privatization instruments are designed to limit this flexibility. One of the key components of these safeguard mechanisms is the specific design of regulatory institutions, and this points to the importance of independent, autonomous, accountable regulatory institutions for sustainable reforms in regulated sectors. A major contribution of the literature is to show that processes, particularly quantitative processes, matter much more than policymakers seem to appreciate. If there are commitment problems, short-term institutional contracts between the various players are more likely to ensure independence and autonomy. This has an impact on the duration of the nomination of the regulators. Short-term contract may be better, yet contracts for regulators are typically between four and eight years, and often include possibilities for renewal.

It may be interesting to point out that the regulation debate also applies to the debate on the accountability of NGOs involved in infrastructure. Ackerman (2004) examines five broad mechanisms use to ensure the accountability of NGOs: reports and disclosure statements, performance assessments and evaluations, participation, self-regulation, and social audits. Each mechanism, distinguished as either a tool or a process, is analyzed along three dimensions of accountability: upward-downward, internal-external, and functional-strategic. Ackerman shows that accountability in practice has emphasized upward and external accountability to donors while downward and internal mechanisms remain comparatively underdeveloped. Moreover, NGOs (as well as many donors) have tended to focus on short-term functional accountability responses at the expense of the longer-term strategic processes needed for lasting social and political changesuggesting a tradeoff between short-term and long-term efficiency and between equity in the typical treatment of stakeholders in the "NGO business." 


\section{Conclusion: Forthcoming Challenges}

This overview of the literature has revealed a somewhat unexpectedly large number of issues. By way of conclusion, this section takes stock of the main ones and in the process defines a policy agenda for the international community interested in ensuring quality of service in infrastructure at a fiscally sustainable rate and with the needs of the poor clearly anchored at the top of the agenda.

At the more general level, the main issue may be the disconnect between the extensive academic evidence on the importance of infrastructure - even if it does not matter equally across countries, regions, and cities-and its weak coverage in Poverty Reduction Strategy Papers, which are becoming the main tool for deciding resource allocations in developing countries. This inconsistency between analytical findings and the participatory processes used to set country priorities is starting to generate concerns among researchers. Though there is little analytically documented evidence yet (for examples, see the WIDER Website reviewing the PRSP experience: http://www.wider.unu.edu), it seems clear that a major change is needed to ensure that resource allocation is consistent with the interest of all, which is something the recent participatory processes organized around the PRSPs have not yet been able to deliver.

To get a sense of fairness in the outcomes of these resource allocation mechanisms, the survey shows that it is necessary to have a better sense of some basic facts on the relationship between infrastructure coverage and household income on the one hand and the match between the allocation of international and local resources to infrastructure inputs and the infrastructure needs associated with the production of the MDGs on the other hand. The cross-sectoral dependency needs to be assessed in a more transparent and quantitative way. The role of the transport sector is again an obvious example. Much more work is needed not only at the multicountry level but also at the country-specific level to asses these interactions in ways that have not been picked up by the PRSP process.

These basic facts are also necessary to get a better sense of the infrastructure macroeconomic financing needs. Currently, for a given country there may be as many views as there are actors (including donors) interested in assessing the needs. Only some sector-specific agencies have generated sector-specific information. Particularly shocking is the information gap on the financing needs of the transport sector-reflecting the fact that there is no international agency advocating for the sector in macro debates as is done by the IEA for energy, ITU for telecom, UN-Habitat for urban environments, and WHO for water and sanitation. Instead, investment needs are assessed on a need basis. For transport the only estimates of investment needs that are starting to circulate widely relate to the added costs of meeting new security requirements in ports and airports. ${ }^{30}$

The very imperfect diagnostics available are sufficient to reveal a huge gap between expenditures and needs, with the resources allocated to infrastructure covering less than half of estimated needs. It is also clear that partnerships with the private sector need to be revisited, which means that the public sector is not yet off the hook and significant public resources will be needed. The poorer a country is, the higher its public sector financing requirements will be.

\footnotetext{
${ }^{30} \mathrm{~A}$ second issue is that the lack of data on investment needs is generally the result of a lack of accountability of international and local communities in terms of the effectiveness of the resources allocated to these sectors. These sectors significantly lag behind health and education in terms of possibilities of measuring the effectiveness of aid in improving the fate of the poorest.
} 
To create the fiscal space needed to finance these public sector contributions, the limitations of the existing public sector accounting frameworks must also be addressed in assessing possible trade-offs between the long-term payoffs of infrastructure expenditures and short-term financial stability. This assessment will be a challenge because there is not even an agreement among academics on the basic measures (for example, what is liquidity in the public sector?). In addition to a good framework, addressing the challenge will also require an investment in basic public sector data. Indeed, some of the basic fiscal debates still stems from the fact that the coverage of fiscal data is only tailored to meet a broad sense of fiscal status in relation to broad macroeconomic concerns but that it does not allow good assessment of sectoral policies.

For the poorest countries in which it is clear that the fiscal space is unlikely to be created any time soon, it seems reasonable to start considering the role of infrastructure grants-for access and sometimes for lifelines for a limited duration at least. The Swiss aid agency is a leader in this field and has a pilot program that needs to be analyzed much more carefully. ${ }^{31}$ For many countries, the main challenge will actually be to come up with designs and choice of new financial instruments that will allow the public sector to leverage any fiscal space available. The need to connect infrastructure development with private financial markets as a way to leverage and mobilize more capital may be the most pressing and the most obvious. Bolivia's capitalization experience and similar efforts in Eastern Europe have shown the possibilities as well as the challenges. Addressing these challenges requires better pooling of risks than in the past. This may require a willingness among donors to work together on the design of new and improved risk mitigation products and applications that allow national and subnational governments to pool risks across sectors and projects more effectively. It will also require, at the project level, improvements in risk allocation mechanisms to address currency and regulatory risks, which are among the greatest contributors to the high cost of capital in developing countries, particularly low-income countries.

This financing debate is taking place in an increasingly complex public sector organizational structure and the evidence reviewed suggests that there is a need to support the redesign of risk allocation mechanisms across government levels (and associated governance structures) to allow each level to optimize access to private financial markets for its infrastructure needs. In the process, the accomplishments and failures of almost 30 years of decentralization must be taken into account looking ahead and not only in terms of service levels but also in terms of cost-effectiveness, targeting, and associated corruption. When the institutional limitations are taken into account, there is reasonable evidence to believe that user fees are still the best way to finance decentralized public services, except when a large share of local users are poor. When intergovernmental transfers and grants take place, there is a need to more systematically assess the impact of corruption and political structures on the optimal financing scheme for infrastructure services across government levels. It is also crucial to be able to assess the relative importance of the urban and rural poor to ensure effective resource allocation. Similar needs assessment are also needed to improve the monitoring of infrastructure-specific community-driven programs. To be effective in internalizing these lessons both in the decentralization and the participation context, a good dose of realism needs to take over from some of the somewhat naïve idealism that continues to prevail in parts of the infrastructure development community.

More generally, from the strict viewpoint of the needs of the poor, because resources are limited and getting the biggest bang for the buck in terms of aid effectiveness is so crucial, getting

${ }^{31}$ See Briceno et al. (2003) for more details 
to know more specifically the size, type, and nature of the importance of the poverty problem in terms of infrastructure policy may be the main challenge to address over the next few years. ${ }^{32}$ Indeed, when basic facts are known and can be studied, they reveal many misconceptions and prejudices which are not necessarily in the interest of the poor. More unfortunate maybe is that some facts well known fom theory and supporting evidence are largely ignored in practicealthough they may be talked about a lot. For instance, to address the needs of the poor, there is an abundance of evidence to show that good economic regulation is needed. There is also plenty of evidence that regulation requires not only legal skills but also highly specialized economic skills to develop and use necessary regulatory instruments. Also, these instruments rely on a lot of the data needed to make the poverty oriented resource allocation decisions discussed earlier. This data is needed to design the right price/tariff structures and target subsidies to meet jointly the fiscal, efficiency and social concerns of policymakers (accounting for the monitoring and enforcement ability of the authorities). ${ }^{33}$ Much of this data, the development of these instruments and the associated training can be, and sometimes have been, financed by loan preparation or technical assistance from donors but not often enough to get effective regulation if the high rate of contract renegotiation is any indication of the problem.

Ultimately, from the experience of the 1990s and the challenges identified in this survey, it seems that the main missing item on the reforms agenda so far has been a serious commitment to provide much more support to the institutional components of infrastructure reformsparticularly the regulatory component, which drives the equity and long-term viability of many operational reforms, including privatization; the design of auction and procurement rules in a sector where in competitive markets low-balling by bidders with limited implementation skills or in much less competitive markets high bids with bidders with strong ex-post negotiation skills; and the coordination between the institutions created or restructured as part of reforms. Effective regulation, procurement rules and institutions are needed to increase transparency and accountability and minimize the effects of corruption on the level, quality, and price of public services being delivered, often by public and private monopolies, to the world's poorest people. ${ }^{34}$ Much more is known from quantitative research on the infrastructure needs of the investment climate and long-term growth than on the needs of residential users, particularly the poor users and on the costs to the public sector of meeting the needs of all users.

Ensuring a fair balance in the monitoring of the winners and losers of reforms (or lack of reforms) will require much better coordination between donors. Indeed, the economic literature surveyed and donors' policy statements point to a wide diversity of concerns and approaches in the infrastructure agenda for developing countries with little joint accountability for outcomes. While every donor is sovereign in its strategies, the incidence of coordination failures is on the countries, not on the agencies. Just as in the case of the MDGs, some basic quantitative agreement

\footnotetext{
32 The original baseline poverty estimates used for the MDGs were based on income and consumption distribution surveys for 44 countries containing 71 percent of the population in 1990 (Ghaiha 2003). These countries accounted for about a quarter of those considered to be developing. Ghaiha also documents the many sources of data and their inconsistencies.

${ }^{33}$ These data and instruments can also be used to assess the regressivity of the use of infrastructure sectors as tax handles which seems to also be an emerging problem from the literature surveyed here.

34 At the same time, it must be recognized that in the context of privatization, when pushed too far, regulation is equivalent to a renationalization of the sector.
} 
is thus needed on what constitutes a common baseline against which progress from all sources of intervention will be measurable. But the coverage cannot only focus on access rate, it will have to account for some other key dimensions of relevance to the assessment of the effectiveness of various reform and aid strategies (i.e. affordability and quality of services to the poor, fiscal cost to the state, financial viability, corruption, and so on). As of today, we know little about progress over any duration on a wide range of indicators of relevance to the poorest simply because the baseline information is not there. Without this baseline, there is no possible collective accountability on the performance of the infrastructure sector and it is a safe bet to assume that the losers of this lack of accountability have been, are and will be the poor. 


\section{Selected Bibliography}

\section{Bibliography for Macro linkages}

Baldwin, R. R. Forslid, P. Martin, G. Ottaviano and F.R. Nicoud (2003), Economic Geography and Public Policy, Princeton University Press

Briceno, C., A. Estache and N. Shafik (2004), "Infrastructure Services In Developing Countries: Access, Quality, Costs and Policy Reform", The World Bank, (forthcoming)

Canning, D., and E. Bennathan, 2000, "The Social Rate of Return on Infrastructure Investment," World Bank, Policy research working paper 2390, Washington, D.C.;

de la Fuente, A. And X. Vives (1995), "Infrastructure and education as instruments of economic policy: Evidence from Spain", Economic Policy, No 20, April

de la Fuente, A. (2002), 'Convergence across countries and regions: theory and empirics," UFAE and IAE Working Papers 555.02, Unitat de Fonaments de l'Anàlisi Econòmica (UAB) and Institut d'Anàlisi Econòmica (CSIC), available at: http://www.eib.org/efs/eibpapers/y00n2v5/y00n2a02.pdf

Esfhani, H. and M.T. Ramirez, M.T. (2003), "Institutions, infrastructure, and economic growth", Journal of Development Economics, April 2003, vol. 70, 2, pp. 443-477(35)

Fujita, M., P. Krugman and A. Venables (1999), The spatial economy: cities, regions and international trade, MIT press, Cambridge

Fujita, M. and J.F. Thisse (2002), Economics of agglomeration, Cambridge University Press

Krugman, P. (1991), "Increasing returns and economic geography", Journal of Political Economy, 99, 483-499

Ramirez, M. D and N. Nazmi (2003), "Public Investment and Economic Growth in Latin America: An Empirical Test," Review of Development Economics, Vol. 7, No. 1, pp.115-126.

\section{Bibliography for MDGs}

Anand, P.B. (2004), "Getting infrastructure priorities right in post conflict reconstruction, presented at the UNU/WIDER Conference on Making Peace Work, available at: http://www.wider.unu.edu/conference/conference-2004-1/conference\%202004-1-papers/Anand1905.pdf

Ballard-Tremeer, G ; Bruce, N; Ezzati, M.; Lvovsky, K.; Smith, K.; von Schirnding, Y. (2000). Addressing the Impact of Household Energy and Indoor Air Pollution in the Health of the Poor - Implications for Policy Action and Intervention Measures. Working Paper WG5: 12. Washington, DC: WHO Commission on Macroeconomics and Health.

Booth,D.(2003), "Introduction and Overview", Development Policy Review, 21(2), pp131-159

Estache, A. V. Foster and Q. Wodon (2002), Accounting for Poverty in Infrastructure Reform - Learning from Latin America's Experience, World Bank Institute Publications, Studies in Development Series 
Fay, M., D. Leipziger, Q. Wodon and T. Yepes (2003), Achieving the Millennium Development Goals: The Role of Infrastructure, Policy research working paper 2390, Washington, D.C.

Government of Vietnam (2001), "Infrastructure and the MDGs" Government-NGO poverty task force, available at http://www.vdic.org.vn/eng/pdf/infra-eng.pdf

Jayasuriya, R. and Q. Wodon (2003), "Efficiency in Reaching the Millenium Development Goals", World Bank Working Paper, No9

Komives, K. \& Whittington, D. \& Wu, X. (2001), Infrastructure Coverage and the Poor: A Global Perspective," World Bank, Policy Research Working Papers, No 2551.

Manning, R. (2004), How can the development community help achieve greater progress towards the MDGs", WIDER public lecture, February 9, 2004

Ravallion, M. (2003), The Debate on Globalization, Poverty, and Inequality: Why Measurement Matters", World Bank, Policy Research Working Papers, No 3038

Sachs, J. (2004), "Doing the Sums on Africa", The Economist, May, available at: http://www.undp.org/mdg/Economist_May\%2020\%202004.pdf

United Nations (2001-2004), Country Reports on MDGs, available at:

http://www.undp.org/mdg/country_regionalreports.html

Wang, L. (2002). "Health Outcomes in Poor Countries and Policy Implications: Empirical Findings from Demographic and Health Surveys”, World Bank, Policy Research Working Paper 2831

\section{Bibliography for Financing needs}

Briceno, C., A. Estache and N. Shafik (2004), "Infrastructure Services In Developing Countries: Access, Quality, Costs and Policy Reform”, The World Bank, (forthcoming)

Chatterjee, S.; Sakoulis, G.; Turnovsky, S.(2003), "Unilateral Capital Transfers, Public Investment, and Economic Growth”, European Economic Review, 47 (6), pp. 1077-1103

Coelli, T., A. Estache, S. Perelman and L. Trujillo (2003), A primer on efficiency measurement for utilities and transport regulators, WBI Development Studies, Washington, $\mathrm{DC}$

Easterly, W. and L. Serven, editors (2003), The Limits of Stabilization, Stanford University Press, Stanford

Fay, M. and T. Yepes (2003), "Investing in Infrastructure: What is needed from 2000-2010", World Bank, Policy Research Working Paper, 3102

Flyvbjerg, B. M. Skamris Holm and S. Buhl, (2003), "How common and how large are cost overrun in transport infrastructure projects", Transport Review, Vo. 23, 1, 71-88

Flyvbjerg, B, N. Bruzelius and W.Rothengatter (2003), Megaprojects and Risk: An Anatomy of Ambition, Cambridge Univiesry Press

IEA (2003), World Energy Outlook, Paris

Kessides, I. (2004), Reforming Infrastructure: Privatization, Regulation, and Competition, Oxford University Press

United Nations (2004), http://www.unmillenniumproject.org/html/docs\%20and\%20reports.shtm.]

United Nations (2004) http://www.unmillenniumproject.org/html/secretariatdocs.shtm. 
WHO (2000), Global Water Supply and Sanitation Assessment, Geneva, available at http://www.who.int/docstore/water_sanitation_health/Globassessment/GlobalTOC.htm

\section{Bibliography for PPI, the macro story}

Briceno, C., A. Estache and N. Shafik (2004), "Infrastructure Services In Developing Countries: Access, Quality, Costs and Policy Reform", The World Bank, (forthcoming)

Easterly, W. and L. Serven, editors (2003), The Limits of Stabilization, Stanford University Press, Stanford

Estache, A. and M.E. Pinglo (2004), "Are returns to Public-Private Infrastructure Partnerships in Developing Countries Consistent with Risks since the Asian Crisis", World Bank, PR Working Paper series, Number 3373

Guasch, J.L. (2004), Granting and Renegotiating Infrastructure Concessions: Doing it Right, WBI Development Studies

Gomez-Ibanez, J.A. (2003), Regulation of Private Infrastructure: Monopoly, contracts and discretion, Harvard University Press

Kessides, I. (2004), Reforming Infrastructure: Privatization, Regulation, and Competition, Oxford University Press

Ramamurti, R. and J. Doh (2004), "Rethinking foreign infrastructure investment in developing countries", Journal of World Business, 39, pp151-167

U.K. Department for International Development, 2002, Making Connections: Infrastructure for Poverty Reduction, London

\section{Bibliography for the Fiscal space debate}

Ballasone, F. and D. Franco (2000), "Public Investment, the Stability Pact and the Golden Rule, Fiscal Policy, vol. 21, 2, pp207-229

Blanchard, O.J. and F. Giavazzi (2003), "Improving the SGP through a Proper Accounting of Public Investment", European Economic Perspective newsletter, CEPR, No1. February

Buiter, W. and C. Grafe (2004), "Patching up the pact: some suggestions for enhancing fiscal sustainability and macroeconomic stability in an enlarged European Union", Economics of Transition v12, n1 (2004): 67-102

Calderon, C. and A. Chong, (2004), "Volume and Quality of Infrastructure and the Distribution of Income: An Empirical Investigation", Review of Income and Wealth, Vol. 50, No. 1, pp. 87-106, March

Easterly, W. and L. Serven, editors (2003), The Limits of Stabilization, Stanford University Press, Stanford

Kalaitzidakis, P. ; S. Kalyvitis (2004), On the Macroeconomic Implications of Maintenance in Public Capital : Journal of Public Economics v88, n3-4, 695-712

McCrae, M. and M. Aiken (2000), "Accounting for infrastructure service delivery by governement: generational issues", Financial Accountability and Management, 16(3), pp265-287 
Reinikka, R. and J. Svensson (2002), "Coping with poor public capital", Journal of Development Economics, 69 (1), pp51-69

Rioja, Felix.K. (2003a), The Penalties of Inefficiency Infrastructure, Review of Development Economics, 7(1), 127-137

Rioja, Felix K.(2003b), Filling Potholes: Macroeconomic Effects of Maintenance vs New Investments in Public Infrastructure", Journal of Public Economics, v87, n9-10: 2281-2304

Turrini, A. (2004), "Public Investment and the EU fiscal framework", EUROPEAN ECONOMY. ECONOMIC PAPERS. No. 202. May, European Commission, available at http://europa.eu.int/comm/economy_finance/publications/economic_papers/economicpapers202_e $\underline{\text { n.htm }}$

\section{Bibliography for the search for new financing mechanisms}

Armstrong, M and D. Sapington (forthcoming), "Recent Developments in the Theory of regulation", in Armstrong, M. and R. Porter, Handbook of Industrial Organization, volume 3, Elsevier: Amsterdam, available as working paper at:

http://www.econ.ucl.ac.uk/downloads/armstrong/reg.pdf

Becht, M., P. Bolton and A. Roell (2004, "Corporate Governance and Control," Literature survey prepared for the Handbook of the Economics of Finance, edited by George Constantinides, Milton Harris and René Stulz, North-Holland, forthcoming

Bos, D. (1994), "Pricing and Price Regulation: An Economic Theory for Public Enterprises and Public Utilities", Advanced Textboks in Economics, Vol. 34, Elsevier/North Holland, Amsterdam - New York - Oxford

Bos, (D), (2003), "Public versus Private Sectors in Public Finance, International Tax and Public Finance 10, pp. 309-508

Bortolotti and Siniscalco (2004), The Challenges of Privatization: An International Perspective, Oxford University Press

Day, J and P. Taylor (2004), "Institutional Change and Debt-Based Corporate Governance: A Comparative Analysis of Four Transition Economies", Journal of Management and Governance, v8, 1, 73-115

Estache, A. and A. Kartasheva (2003), Recent theoretical work on capital market imperfections and financing arrangements: lesson for infrastructure financing in LDCs, mimeo, The World Bank

Esty, Benjamin C (2004), 'Why Study Large Projects? An Introduction to Research on Project Finance", European Financial Management, no. 2:213-224

Freire, M.E. and J. Perterson (2004), Subnational Capital Markets: Theory and Practice, Oxford University Press

Hart, O. (2003), "Incomplete Contracts and Public Ownership: Remarks and an application to PPP", The Economic Journal, 113, C69-C76

Irwin, T. (2003). Public money for private infrastructure : deciding when to offer guarantees, output-based subsidies, and other forms of fiscal support for privately provided infrastructure services, World Bank Working Paper, No. 10 
Laffont, J.J. and J. Tirole (1993), A theory of Incentives in Regulation and Procurement, MIT press, Cambridge

Laffont, J.J. (2000), Incentives and Political Economy, Oxford University Press

Laffont, J.J. (2004), Regulation and Development, Cambridge University Press (forthcoming)

Legros, P. and E. Iossa (2004)), “Auditing and Property Rights," Rand Journal of Economics, forthcoming.

Lewis, B. (2003), "Local Government Borrowing and Repayment in Indonesia: Does Fiscal Capacity Matter?" World Development, 31, 6, 1047-1063

Litan, Robert E.; Pomerleano, Michael; Sundararajan, Vasudevan, eds. (2003), The future of domestic capital markets in developing countries, Washington, D.C.: Brookings Institution

Marrison, Chris. "Risk Measurement for Project Finance Guarantees." Journal g Project Finance. 2001. Summer

Newberry (2000), "Privatization, Restructuring, and Regulation of Network Utilities, MIT Press, Cambridge

Von Hirshchausen, C. (2002), Modernizing Infrastructures in Transition economies: Paving the Way to European Enlargement, Cheltenham: Edward Elgar

\section{Bibliography for Urban vs. Rural poor}

Booth, A. (2004), "Africa or Asia? The Development Challenges Facing Eastern Indonesia and East Timor", Oxford Development Studies, 32 (1), pp19-35

Cohen, B. (2004), Urban Growth in Developing Countries: A review of current trends and a caution regarding esitsing forecasts", World Development, 32 (1), 23-51

Ellis, F. (1998), "Household strategies and rural livelihood diversification", The Journal of Development Studies, 35(1), pp1-38

Fan, S.; Zhang, L.; Zhang, X. (2004), Reforms, investment, and poverty in rural China. Economic Development and Cultural Change 52(2): 395-421

Fan, S.; Jitsuchon, S.; Methakunnavut, N.. (2004a). The importance of public investment for reducing rural poverty in middle-income countries : the case of Thailand. (Discussion Paper) Washington, D.C.: International Food Policy Research Institute (IFPRI), available at http://www.ifpri.org/divs/dsgd/dp/papers/dsgdp07.pdf

Fan, S.; Zhang, X.; Rao, N. (2004b) Public expenditure, growth, and poverty reduction in rural Uganda (Discussion Paper) Washington, D.C.: International Food Policy Research Institute, available at http://www.ifpri.org/divs/dsgd/dp/papers/dsgdp04.pdf

Fan, S. and C. Chan-Kang (2004c), Road Development, Economic Growth and Poverty Reduction in China, (Discussion Paper) Washington, D.C.: International Food Policy Research Institute, available at: http://www.ifpri.org/divs/dsgd/dp/papers/dsgdp12.pdf

Gaiha, R. (2003), “ Are Millenium Goals of Poverty Reduction Useful?, Oxford Development Studies, 31 (1), 59-84

Harvard, L. M. Ruel nd J. Garrett (1999), «Are urban poverty and undernutrition growing? Some newly assembled evidence”, World Development, 27 (11), 1891-1904 
Lipton, M. (1977), Why poor people stay poor: Urban Bias in World Development, Harvard University Press, Cambridge, MA.

Mellor, J. (1976), The New Economics of Growth: A strategy for India and the Developing World, Cornell University Press, Ithaca, NY.

Mwabu, G. and E. Thorbecke (2004), "Rural development, growth and poverty in Africa", Journal of African Economies, 13, AERC Supplement 1, ppil16-i65

Ravallion, M. (2002), 'On the Urbanization of Poverty," Journal of Development Economics, 68(2), 435-442

Reardon, T. (2001), "Rural Non-Fram Income in developing countries, report to the FAO, available at http://econ.worldbank.org/files/26753_treardon.pdf

Sahn, D., D. Stifel and S. Younger (2003), "Exploring Alternative Measures of Welfare in the Absence of Expenditure Data", Review of Income and Wealth, 49(4), pp463-489

Sahn, D. and Stifel

Van de Walle, D. And D. Cratty (2004), "Is the emerging non-farm market economy the route out of poverty in Vietnam?", Economics of Transition, 12 (2), 237-275

Vernon, V. (2002), "Urbanization in Developing Countries", World Bank Research Observer, 17(1), pp89-112

\section{Bibliography for decentralization and participation}

Ackerman, J. (2004), "Co-Governance for Accountability: Beyond "Exit" and "Voice"', World Development, Vol. 32 ( 3); p. 447

Bardhan, P and D. Mookherjee (2003), "Decentralization and accountability in infrastructure in developing countries", Boston University, mimeo, available at:

http://www.bu.edu/econ/Working\%20Papers/papers/Dilip\%20Mookherjee/ddinf.pdf

Bardhan, P. (2004), "Governance Issues in Delivery of Public Services", Journal of African Economies, 13, AERC Supplement 1, ppil67-il82

Bardhan, P and D. Mookherjee (forthcoming), "Corruption and decentralization of infrastructure in developing countries", Economic Journal, available in draft at:

http://www.econ.yale.edu/ egcenter/decdelinf.pdf

Beesley, T. and S. Coate (2003), "Centralized vs. decentralized provision of local public goods: a political economy approach", Journal of Public Economics, 87 (12), pp2611-2637

Chuwa, E.W., E. K. Zovu and P.M. Mbula (2002), "Participation and Impact of Poverty Oriented Public Works Projects in Rural Malawi”, Development Policy Review, 20 (2), 159-176

Cornwall, A. (2003), "Whose voices" Whose choices" Reflectsion on genger and participatory development", World Development, 31 (8), 1325

Cremer, J. A. Estache and P. Seabright (1996), "Decentralizing Public Services: what can we learn from the Theory of the Firm?", Revue d'Economie Politique, 106 (1),

Estache and Sinha (1995), "Does decentralization increase spending on infrastructure?", World Bank, Policy Research Working Paper, Number 1995

Estache (1995), Decentralizing Infrastructure: Advantages and Limitations (1995), editor, World Bank Discussion Paper No 29 
Estache, A. and D. Martimort (2000), “Transaction costs, politics, regulatory institutions and regulatory outcomes", in Manzetti, L. ed. (2000), Regulatory Policy in Latin America: PostPrivatization Realities, North-South Press Center at the University of Miami pp 49-82

Faguet, J.P (2003), "Does decentralization increase government responsiveness to local needs: Evidence from Bolivia", Journal of Public Economics

Ghazala, M. (2004), "Community-based and -driven development: a critical review"”, World Bank Research Observer, 19 (1), 1-39

Isham, J., D. Narayan and L. Pritchett (1995), Does Participation Improve Performance? Establishing Causality with Subjective Data", World Bank Economic Review, Vol. 9(2), pp175-200

Kleemeier, E. (2000), "The impact of participation on sustainability: an analysis of the Malawi Rural Piped Scheme Program”, World Development ,29(5), 929-944

Laffont, J.J. (2000), Incentives and Political Economy, Oxford University Press

Laffont, J.J., A. Faure-Grimaud and D. Martimort (2003), Collusion, Supervision with Soft Information", Review of Economic Studies, vol. 70, n. 2, 2003, p. 253-280

Mody, S. (2004), Achieving Accountability through Decentralization: Lessons for Integrated River Basin Management, World Bank, PR Working Paper series, Number 3346

Poitevin, M. (2000), "Can the theory of incentives explain decentralization?" Canadian Journal of Eocnomics, Vol.33 (4), pp 878-906

Serageldin, M., S. Kim and S. Whaba (2000), "Decentralization and Urban Infrastructure Management Capacity", Harvard University, Center for Urban Development Studies, available at: http://www.gsd.harvard.edu/research/research_centers/cuds/decentralization_paper/decentralizatio n.pdf

Shah, A. T. Thompson and H.F. Zhou (2004), "The Impact of Decentralization on Service Delivery, Corruption, Fiscal Management and Growth in Developing and Emerging Market Economies: A Synthesis of Empirical Evidence", CESifo Dice Report 2: 10-14

Turk, C. (2001), "Linking Participatory Poverty Assessments to Policy and Policymaking: Experience from Vietnam", World Bank., Policy Research Working Paper, No.2526

Walker, I et al. (1999), Regional analysis of decentralization of water supply and sanitation services in Central America and the Dominican Republic, EHP activity report N. 65, available at http://www.dec.org/pdf_docs/PNACF340.pdf

World Development Report (2004), Making Services Work for the Poor, World Bank

\section{Bibliography for targeting, affordability and regulation}

Ajwad, M.I.. and Q. Wodon (forthcoming) "Marginal Benefit Incidence Analysis Using a Single Cross-section of Data", Applied Economic Letters

Ajwad, M.I.. and Q. Wodon (2002), "Who benefits from increased access to public services at the local level? A marginal benefit incidence for education and basic infrastructure:, in S. Devaradjan and F.H. Rogers, editors, World Bank Economists' Forum, Volume 2, World Bank, Washington DC, 155-175

Andersen, L.E. and R. Faris (2002), "Natural Gas and Income Distribution in Bolivia", February, Andean Competitiveness Project Working Paper 
Atkinson, A.B. and F. Bourguignon (2000), Handbook of Income Distribution, Volume I, North Holland, Amsterdam

Baker, J (2003), Evaluating the Poverty Impact of Projects: A Handbook for Practitioners, The Word Bank, for more details, see:

http://info.worldbank.org/etools/bSPAN/PresentationPrint.asp?PID=651\&EID=327

Banerjee, A., R. Benabou and D. Mookherjee eds. (2004), What have we learnt about poverty?, Oxford University Press

http://www.bu.edu/econ/Working\% 20Papers/papers/Dilip\% 20Mookherjee/ddinf.pdf

Benabou, R. (2000), Unequal Societies: Income Distribution and the Social Contract", American Economic Review, 90(1), 96-129

Boland, J. and D. Whittington (2000), "The political economy of increasing block water tariff design in developing countries", in Dinar (2002)

Bourguignon, F. and L.A. Pereira da Silva 2003), The Impact of Economic Policies on Poverty and Income Distribution-Evaluation Techniques and Tools, Oxford University Press

Brook, P. and T. Irwin (2003), Infrastructure for poor people: public policy for private provision, The World Bank, Washington, DC

Chong, A. and F. Lopez de Silanes (2003). "The Truth about Privatization in Latin America," a preview is available as Yale School of Management Working Papers, number 436, Yale School of Management.

Clarke, G. and S. Wallsten (2002), "Universal(ly Bad) Service: Providing Infrastructure Services to Rural and Poor Urban Consumers", World Bank, Policy Research Working Paper, 2868

Chisari, O., A. Estache and C. Romero (1999), "Winners and Losers from the Privatization and Regulation of Utilities: Lessons from a General Equilibrium Model of Argentina" (1999), The World Bank Economic Review, Vol. 13, No 2.), pp. 357-378

Chisari, O., A. Estache and C. Waddams-Price (2003), "Access by the poor in Latin America's utility reform: subsidies and service obligations" in Ugaz, C. and C. Waddams Price, ed. (2003), Utility Privatization and Regulation: A Fair Deal for Consumers?, Edward Elgar, Northampton, MAS, USA (with O. Chisari and C. Waddams Price)

Cremer, H., F. Gasmi, A. Grimaud and J.J. Laffont (2001), "Universal Service: an Economic Perspective Overview", Annals of Public and Cooperative Economics, vol. 72, n. 1

Danziger, S. H. and R. H. Haverman (2001), eds. Understanding Poverty, Russell Sage Foundation, New York

Deaton, A. (1996) Microeconometric Analysis for Development Policy: Approach to Analyzing Household Surveys, John Hopkins University Press, Baltimore

Dinar, A. (2000), The Political Economy of Water Pricing Reform, Oxford University Press

Duclos, J.Y. , P. Makdissi and Q.Wodon (2004), "Poverty-efficient Program Reforms: The Role of Targeting and Allocation Rules," Journal of Development Economics, forthcoming

Duflo, E (2003), Scaling Up and Evaluation, MIT, mimeo

Duflo, E. and M. Kremer (2003), Use of Randomization in the Evaluation of Development Effectiveness, , MIT, mimeo 
Elbers, C. J. Lanjouw, and P. Lanjouw (2003), "Micro-Level Estimation of Poverty and Inequality," Econometrica, pp355-364

Elbers, C. and Lanjouw P. (2001) Intersectoral Transfer, Growth and Inequality in Rural Ecuador ,World Development, 29/3, 481-496.

Estache, A. (2004), “Argentina Privatization: A Cure or a Disease?" in Hirschhausen, Christian, Thorsten Beckers and Kay Mitusch, Trends in Infrastructure Regulation and Financing: International Experience and Case Studies from Germany, Edward Elgar, Cheltenham, UK and Northampton, MA., USA

Estache, A. V. Foster and Q. Wodon (2002), Accounting for Poverty in Infrastructure Reform - Learning from Latin America's Experience, World Bank Institute Publications, Studies in Development Series

Foster, V., A. Gomez-Lobo, and J. Halpern (2000a), Better Household Surveys for better Design of Infrastructure Subsidies, Public Policy for the Private Sector, Note 213, available at http://rru.worldbank.org/Documents/PublicPolicyJournal/213gomez.pdf

Foster, V., A. Gomez-Lobo, and J. Halpern (2000b), "Designing Direct Subsidies for Water and Sanitation Services. Panama: a Case Study," World Bank, Policy Research Papers 2344, Washington, DC

Foster, V. and O. Irusta (2003), "Does Infrastructure Reform Work for the Poor? A Case Study on the Cities of La Paz and El Alo in Bolivia", World Bank, Policy Research Papers, No3177, Washington, DC

Foster, V. and M.C. Araujo (2004), "Does Infrastructure Reform Work for the Poor? A Case Study from Guatemala", World Bank, Policy Research Papers, No3185, Washington, DC

Galasso, E. and M. Ravallion (2004), Decentralized targeting of an antipoverty program, Journal of Public Economics, forthcoming

Gasmi, F. , M.D. Kennet, J.J. Laffont and W.W. Sharkey (2002), Cost Proxy Models and Telecommunications Policy, The MIT Press, Cambridge

Gomez-Lobo and D. Contreras (2003), Water subsidy policies: a comparison of the Chilean and Colombian Schemes, The World Bank Economic Review, Vol. 17(3), pp391

Kessides, I. (2004), Reforming Infrastructure: Privatization, Regulation, and Competition, Oxford University Press

Laffont, J.J. and J. Tirole (1993), A theory of Incentives in Regulation and Procurement, MIT press, Cambridge

Laffont, J.J. and J. Tirole (1999), Competition in Telecommunications, MIT Press, Cambridge

Lanjouw, P. and M. Ravallion (1999), Benefit incidence and the timing of program capture", World Bank Economic Review, 257-274

Lanjouw, J. O. and Lanjouw, P. (2001a): How to Compare Apples and Oranges: Poverty Measurement Based on Different Definitions of Consumption, Review of Income and Wealth, $47(1), 25-42$.

Lanjouw, J. O. and Lanjouw, P. (2001b): The Rural Nonfarm Sector: Issues and Evidence from Developing Countries, Agricultural Economics, 26, pg 1-23.

Lanjouw, P., Quizon, J. and Sparrow, R. (2001) Non-Agricultural Earnings in Peri-urban Areas of Tanzania: Evidence from Household Survey Data, Food Policy, 26(4), August, pg 385404. 
McKenzie, D. and D. Mookherjee (2004), The Distributive Impact of Privatization in Latin America: Evidence from Four Countries, Economia, Spring 2003, 161-218

Makdissi, P. and Q. Wodon (2004a), Measuring Poverty Reduction and Targeting

Performance Under Multiple Government Programs", Review of Development Economics, forthcoming

Makdissi, P and Q. Wodon (2004b), "Fuel Poverty and Access to Electricity: Comparing Households When They Differ in Need", Applied Economics, forthcoming

Navajas F. (2000), "El impacto distributivo de los cambios en los precios relativos en la Argentina entre 1988-1998 y los efectos de las privatizaciones y la desregulación económica" in

La Distribución del Ingreso en la Argentina. Fundación de Investigaciones Económicas Latinoamericanas. Buenos Aires, Argentina: FIEL.

Nellis, J. and N. Birdsall, N. (2004), Glass Half Full: Assessing the Distributional Impact of Privatization, The Center for Global Development, Washington, D.C (forthcoming)

Ravallion, M. and M. Lipton (1995), "Poverty and Policy", in Behrman, J. and T. Srinivasan, Handbook of Development Economics, Volume III, Amsterdam; North Holland.

Ravallion, M. (1999a), “Are poor states worse at targeting their poor?", Economic Letters, 65, 373-377

Ravallion, M. (1999b), “Is more targeting consistent with less spending?", International Tax and Public Finance, 6, 411-418

Ravallion, M. (2000), "Monitoring targeting performance when decentralized allocations to the poor are unobserved", World Bank Economic Review, 14 (2), 331-345

Ravallion, M. (2003), "Targeted Transfers in Poor Countries: Revisiting the Tradeoffs and Policy Options", World Bank Policy Research Working Paper, No. 3048

Sahn, D., D. Stifel and S. Younger (2003), "Exploring Alternative Measures of Welfare in the Absence of Expenditure Data", Review of Income and Wealth, 49(4), pp463-489

Ugaz, C. and C. Waddams Price, ed. (2003), Utility Privatization and Regulation: A Fair Deal for Consumers?, Edward Elgar, Northampton, MAS, USA

Van de Walle, D. And K. Nead (1995), Public Spending and the Poor: Theory an Evidence, John Hopkins Press, Baltimore

Van de Walle, D. (1998a), "Infrastructure and Poverty in Viet Nam." In Dollar, Glewwe and Litvack, eds., Household Welfare and Vietnam's Transition to a Market Economy, World Bank, Washington, DC.

Van de Walle, D. (1998b), "Targeting Revisited," World Bank Research Observer,13(2): 23148.

Van de Walle, D. (2002), "Choosing Rural Road Investments to Reduce Poverty," World Development, 30(4): 575-589

Van de Walle, D. (2003), "Are Returns to Investment Lower for the Poor? Human and Physical Capital Interactions in Rural Viet Nam", Review of Development Economics, 7(4): 63653, 2003.

Wodon, Q. , M.I. Ajwad and C. Siaens (2004), “ Lifeline or Means-Testing? Electric Utility Subsidies in Honduras", in P. Brook and T. Irwin, editors

Wodon, Q. (1997), “Targeting the Poor Using ROC Curves”, World Development, 25, pp 2083-92 
Wodon and S. Yitzhaki (2002), "Evaluating the Impact of Government Programs on Social Welfare: The Role of Targeting and the Allocation Rules Among Program Beneficiaries," Public Finance Review

\section{Bibliography for corruption}

Ackerman, J. (2004), "Co-Governance for Accountability: Beyond "Exit" and "Voice"', World Development, Vol. 32 ( 3); p. 447

Aidt, T. S. (2003), Economic Analysis of Corruption: A Survey", The Economic Journal, 113, F632-F652

Armstrong, M. and J.C. Rochet (1999), "Multidimensional screening: a user's guide", European Economic Review, 43: 959-979

Bardhan and Mookherjee, (2000b), P. Bardhan and D. Mookherjee, Capture and governance at local and national levels. American Economic Review 902 (2000), pp. 135-139

Bardhan, P and D. Mookherjee (2003), "Decentralization and accountability in infrastructure in developing countries", Boston University, mimeo

Bardhan, P. (2004), "Governance Issues in Delivery of Public Services", Journal of African Economies, 13, AERC Supplement 1, ppil67-il82

Bardhan, P and D. Mookherjee (forthcoming), "Corruption and decentralization of infrastructure in developing countries", Economic Journal, available in draft at:

http://www.econ.yale.edu/ egcenter/decdelinf.pdf

Boehm, F and Polanco (2003), "Corruption and privatization of infrastructure in developing countries", Transparency International, working paper 1, available at http://www.transparency.org/integrity_pact/resources/working_papers/dnld/wk1_boehm_polanco. pdf

Campos, J., A. Estache and L. Trujillo (2003), "Processes and accounting matter for regulators: Learning from Argentina's railways privatization", Journal of Network Industries, Vol. 4, No1, 3-28

Celentani, M. JJ. Ganiuza and L.L. Peydro (2004), “Combating corruption in international business transactions", Economica, 71, August., 417-448

Clarke, G. and C. Xhu (2004), "Privatization, Competition and Corruption: How characteristics of Bribe takers and Payers Affect Bribes to Utilities", Journal of Public Economics, Vol. ( 9-10), pp 2067-2097

Davies, J. (2004), "Corruption in Public Service Delivery: Experience from South Asia's Water and Sanitation Sector", World Development, 32 (1), pp53-71

Ebrahim, A. (2003), "Accountability in practice: Mechanisms for NGOs », World Development, vol. 31 (5); p. 813

Estache, A., M. Rodriguez-Pardina, J.M Rodriguez and G. Sember (2003), "An Introduction to Financial and Economic Modeling for Utility Regulators", World Bank., Policy Research Working Paper

Estache, A. and E. Kouassi (2002), "Sector Organization, Governance, and the Inefficiency of African Water Utilities', World Bank Research Working Paper 2890 
Flyvbjerg, B. M. Skamris Holm and S. Buhl, (2003a), "How common and how large are cost overrun in transport infrastructure projects", Transport Review, Vo. 23, 1, 71-88

Flyvbjerg, B, N. Bruzelius and W.Rothengatter (2003b), Megaprojects and Risk: An Anatomy of Ambition, Cambridge University Press

Flyvbjerg, B. M. Skamris Holm and S. Buhl, (2002), "Cost underestimation public works projects: error or lie?:, Journal of the American Planning Association, 68, 279-295

Friends of the Earth (2001), Dirty Water: The environemtal and social record of four multinational water companies, London

Global Corruption Report (2004), available at http://www.globalcorruptionreport.org/

Guasch, J.L. (2004), Granting and Renegotiating Infrastructure Concessions: Doing it Right, WBI Development Studies

Kaufman, D. , A. Kraay and M. Mastruzzi (2003), Governance matters III: Governance Indicators for 1996-2002”, June 30 draft, World Bank, available at www.worldbank.org/wbi/governance

Khalil, F. and J. Lawarree (2001), "Catching the agent on the wrong foot: ex-post choice of monitoring", Journal of Public Economics, vol.82, pp.327-347

Hall, D. and E. Lobina (2002), "Water Privatization in Latin America 2002" Public Service International Research Unit, Universit y of Greenwich

Laffont, J.J. and M Meleu (1999), "A positive theory of privatisation for sub-Saharan Africa", Journal of African Economies, 8: 30-67.

Laffont, J.J., A. Faure-Grimaud and D. Martimort (1999), "The Endogenous Transaction Costs of Delegated Audition", European Economic Review, vol. 43, 1999, p. 1039-1048

Laffont, J.J. and T. N'Guessan (1999), "Competition and corruption in an agency relationship", Journal of Development Economics, 60, 271-295

Laffont, J.J. (2000), Incentives and Political Economy, Oxford University Press

Laffont, J.J. and D. Martimort (2001), The Theory of Incentives: The Principal-Agent Model, Princeton University Press

Laffont, J.J. (2004), Regulation and Development, Cambridge University Press (forthcoming)

Lanyi, A. (2004), "Measuring the economic impact of corruption”, The IRIS Discussion Paper series on Institutions \& Development, University of Maryland, Paper 04/04

Lovei, L. (1998): “Gas Reform in Ukraine: Monopolies, Markets, and Corruption”, Public Policy Journal ,169, available at:

http://rru.worldbank.org/PublicPolicyJournal/Summary.aspx?id=169

Lovei, L and A. McKechnie (2000), "The Costs of Corruption for the Poor: The Energy Sector", Public Policy Journal, 207, available at: http://rru.worldbank.org/PublicPolicyJournal/Summary.aspx?id=207

Mitlin, D. (2002), "Competition, regulation and the Urban Poor", Center on Regulation and Competition, CRC, Working Paper No.37, University of Manchester

Nwankwo, S. and D. C. Richards (2001), "Privatization: The myth of free market orthodoxy in SSA", The International Journal of Public Sctor Management, Vol. 14(2), pp165-179 
Shah, A. T. Thompson and H.F. Zhou (2004), "The Impact of Decentralization on Service Delivery, Corruption, Fiscal Management and Growth in Developing and Emerging Market Economies: A Synthesis of Empirical Evidence", CESifo Dice Report 2: pp.10-14

Reinikka, R. and J. Svensson (2002), "Coping with poor public capital", Journal of Development Economics, 69 (1), pp51-69

Shapiro, C and R. Willig (1990), "Economic rationale for the scope for privatization", in E.N. Suleiman and J. Waterbury (eds), The political economy of public sector reform, Westview Press

Shleifer, A. and R. Vishny (1994), "Corruption”, Quarterly Journal of Economics, 109, pp995-1025

Svensson, J. (2003), "Who must pay bribes and how much? Evidence from a cross section of firms”, Quarterly Journal of Economics, Vol. CXVIII, February, 208-230

Rock, M.T. and H. Bonnett (2004), "The comparative politics of corruption: Accounting for the East Asian paradox in empirical studies of corruption, growth and investment", World Development, 32(6), pp999-1017

Rossi, M. and E. Del Bo (2004), "Corruption and Inefficiency: Theory and Cross-Country Evidence from Electricity Distribution Firms", in Rossi, M (2004), Essays in Applied

Regulatory Economics, PhD thesis, University of Oxford, available at http://users.ox.ac.uk/ rossi/Paper\%202.pdf

Tanzi, V. andH. Davoodi (1997), Corruption, Public Investment and Growth", IMF Working Paper, No 97/139, available at http://www.imf.org/external/pubs/ft/wp/wp97139.pdf

wb14570

$\mathrm{N}:$ Antonioltena2 povnet \survey of infrastructure issues - WP version.doc

September 29, 2004 10:31 AM 